\title{
Nearshore transgressive black shale from the Middle Jurassic shallow-marine succession from southern Poland
}

\author{
Paulina Leonowicz ${ }^{1}$
}

Received: 17 November 2015 / Accepted: 12 March 2016 / Published online: 29 March 2016

(C) The Author(s) 2016. This article is published with open access at Springerlink.com

\begin{abstract}
Five facies types are distinguished in the Middle Jurassic dark-grey mudstone of the Częstochowa OreBearing Clay Formation on the basis of sedimentary structures, bioturbation intensity, and composition of trace fossil and benthic fauna associations. Three of them, laminated mudstone $\left(\mathrm{M}_{1}\right)$, laminated claystone $\left(\mathrm{C}_{1}\right)$, and alternating laminated and bioturbated mudstone $\left(\mathrm{M}_{\mathrm{a}}\right)$, are varieties of black shale. They formed in relatively shallow water, several tens of meters deep, in an epicontinental sea, mainly during the early phase of Middle Jurassic transgression. Suboxic conditions developed beneath a temporary pycnocline in a narrow, proximal zone near flooded land, which delivered increased amounts of organic matter and nutrients, triggering plankton blooms. Oxygen-deficient conditions were recurrently interrupted by re-oxygenation events, linked with the activity of storm-generated bottom currents, which simultaneously redistributed significant amounts of sediment from the basin-margin shoreface zones. Oxygenation improvement varied in duration from single storms to periods lasting several tens of years. The association of laminated mudstone with the beginning of major transgression, relatively shallow water, frequent oxygenation of the sea floor, and the occurrence of betteroxygenated time-equivalent facies in more distal settings, indicates that these deposits represent nearshore transgressive black shale. The limited occurrence of black shale and its poor correlation with minor transgressive-regressive cycles show that its formation depended mainly on local
\end{abstract}

Paulina Leonowicz

paulina.leonowicz@uw.edu.pl

1 Faculty of Geology, University of Warsaw, Żwirki i Wigury 93, 02-089 Warsaw, Poland conditions, which were only partly influenced by relative sea-level changes within the basin.

Keywords Black shale - Oxygen-deficient conditions · Shallow-marine mudstone - Middle Jurassic transgression • Ore-bearing clay $\cdot$ Silesian-Kraków region

\section{Introduction}

Black shales are dark-colored fine-grained rocks, displaying paleoecological, geochemical, and sedimentological features, which point to their deposition in an oxygendeficient environment (Tyson 1987). Typically, they possess a fine parallel lamination, undisturbed by benthic organisms, and a high organic content (TOC $>1 \%$ ), responsible together with dispersed iron sulphides for their dark color (Wetzel 1991a; Arthur and Sageman 1994). The studies of ancient and modern deposits show that their formation can be commonly linked with the interplay of several factors, including high rates of organic productivity, restricted circulation leading to the development of anoxia, and an elevated or reduced sedimentation rate, responsible for concentration and preservation of organic matter (e.g., Wignall 1994; Katz 2005; Tyson 2005). Black shales have been deposited throughout geological time, from the early Proterozoic to the present day (Klemme and Ulmishek 1991), in various environments ranging from the deep sea to lagoons and lakes (Wignall 1994). The most widespread and economically important successions accumulated in marine basins during transgressions and were predominantly associated with the basal part of transgressive systems tracts and with sea-level highstand (Arthur and Sageman 1994; Wignall 1994). 


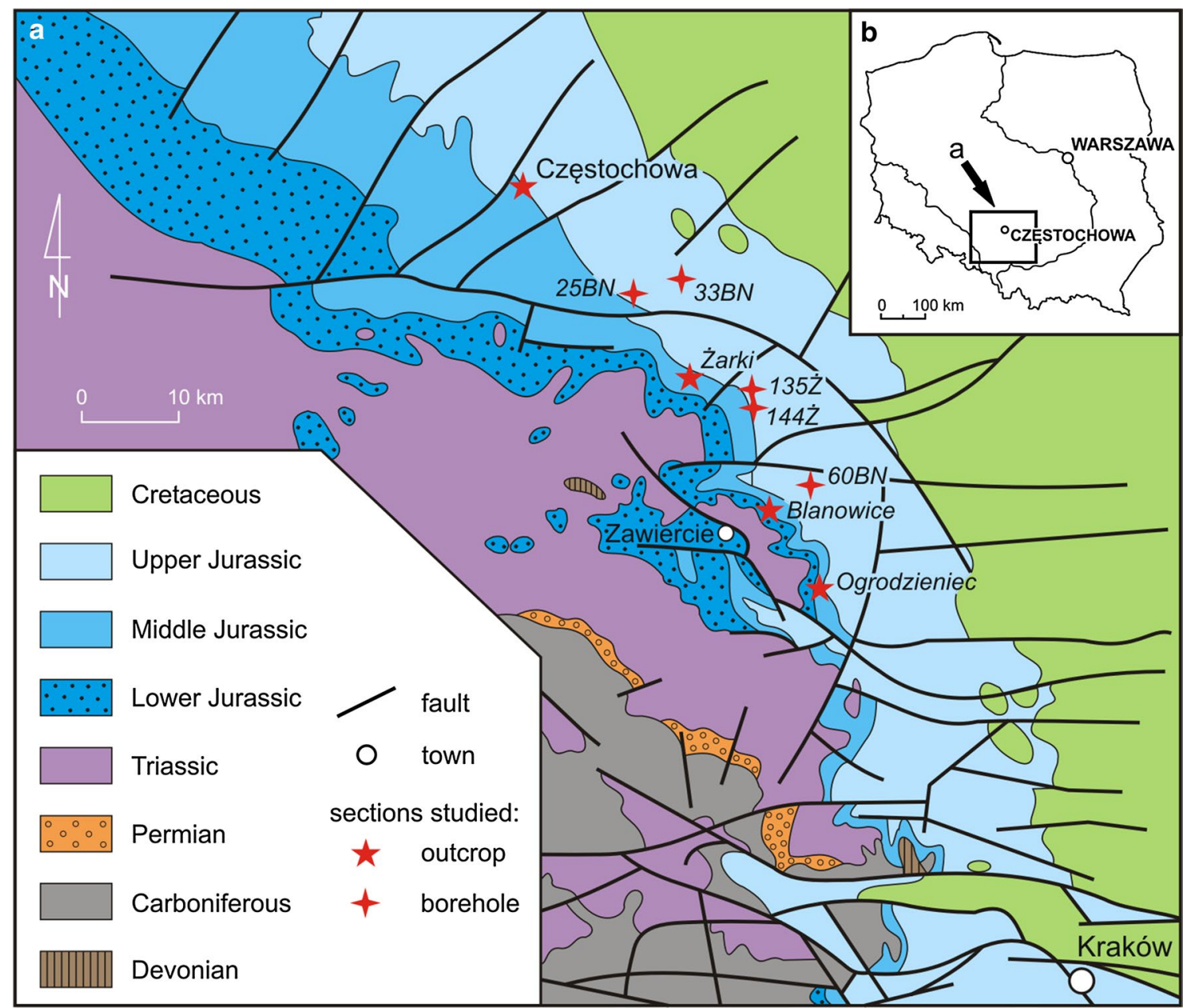

Fig. 1 a Geological map of the Silesian-Kraków Upland (after Dadlez et al. 2000, simplified) and the location of sections studied. b Location of the area shown on a. Boreholes: Biskupice 25BN, Zrębice 33BN, Łutowiec 135Ż, Jaworznik 144Ż, Piaseczno 60BN

This paper describes black shale of the Częstochowa Ore-Bearing Clay Formation from the Middle Jurassic succession of southern Poland (Fig. 1), which represents a specific category of shallow-marine sediment, classified by Wignall and Newton (2001) as "transgressive nearshore black shale". Contrary to most transgressive black shales, which accumulated beneath a stagnant water column and represent the deepest-water sediment at time of their formation (Wignall 1994), this black shale in Poland was deposited in a relatively shallow, high-energy environment, in which oxygenation of the sea floor fluctuated frequently. The Częstochowa Ore-Bearing Clay Formation has already been the subject of several geochemical, paleontological, and sedimentological studies, which have provided relevant information about sedimentary processes and benthic conditions (e.g., Marynowski et al. 2007; Szczepanik et al. 2007; Gedl et al. 2012; Leonowicz 2013, 2015a, b). However, the focus has been on deposits exposed in clay pits, which represent a limited stratigraphic interval. The aim of the present study is the characterization of the complete succession from the southern part of the Silesian-Kraków region, recording the transgression of the Middle Jurassic sea across the Małopolska Land. The correlation of borehole sections and previously studied exposures has enabled a reconstruction of the spatial distribution of the black shale, the interpretation of its position within the depositional sequence, and discussion of the likely mechanisms responsible for its formation.

\section{Geological setting}

The studied deposits constitute part of a marine muddy succession, referred to as the Częstochowa Ore-Bearing Clay Formation (Fig. 2a), which belongs to an extensive Middle Jurassic siliciclastic complex, occurring in a wide area of the Polish Lowlands and Uplands. The Częstochowa OreBearing Clay Formation, known also as the ore-bearing clay, crops out in the Silesian-Kraków Upland in southern 


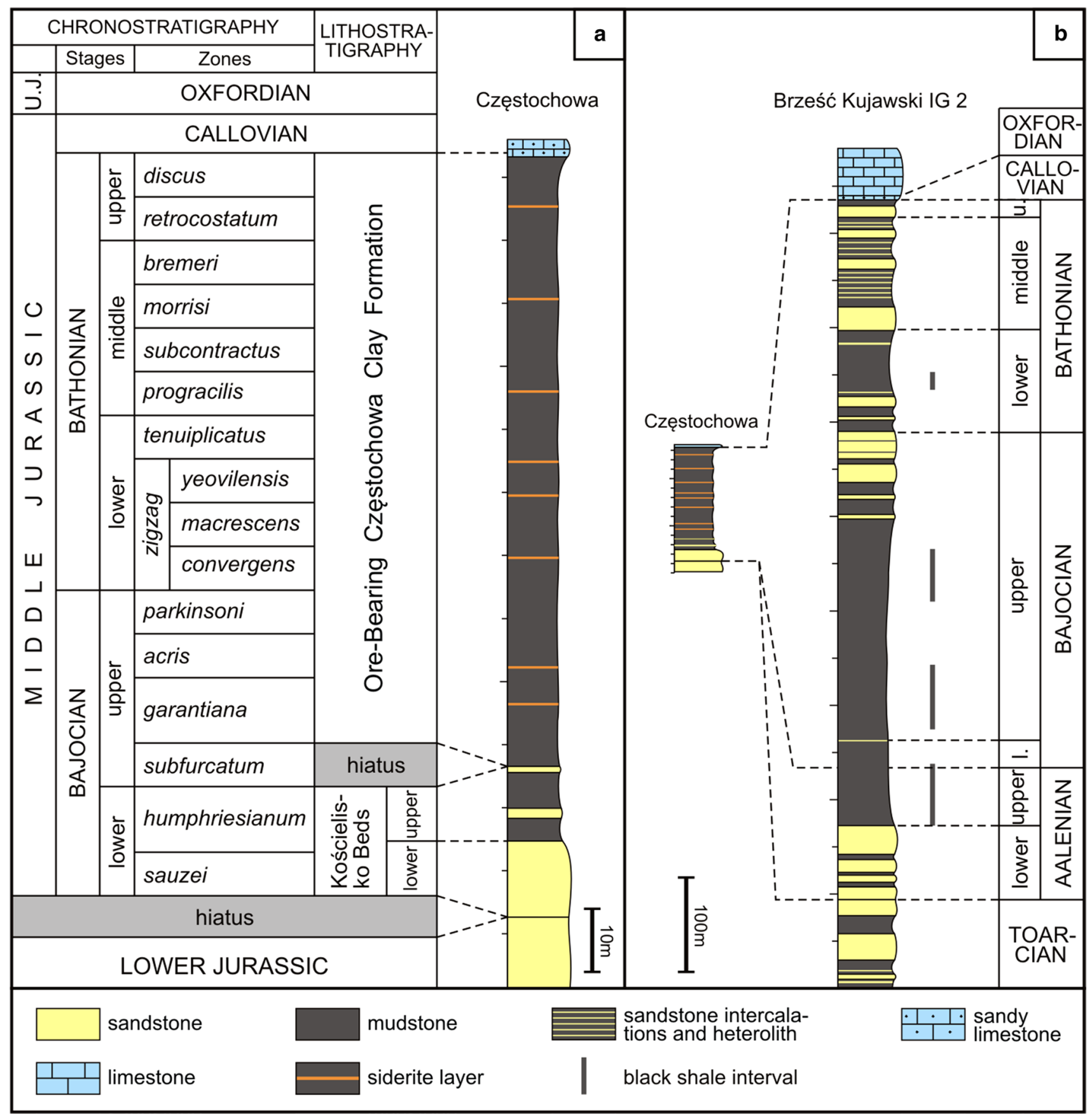

Fig. 2 a Lithostratigraphy and biostratigraphy of the Middle Jurassic deposits from the Silesian-Kraków region (after Kopik 1998; Matyja and Wierzbowski 2000, 2006b; Barski et al. 2004) with an idealized lithological $\log$ from the Częstochowa region. b Lithological log

Poland, in a narrow, NW-SE-oriented belt, which is a part of the Silesian-Kraków Monocline, constructed of Permian and Mesozoic rocks (Fig. 1). The age of the orebearing clay was determined by ammonites as Late Bajocian-Late Bathonian (garantiana-discus chrons: Kopik 1998; Matyja and Wierzbowski 2000, 2006b; Barski et al. from (a) compared with representative section of Brześć Kujawski IG 2 from the Mid Polish Trough zone (after Dayczak-Calikowska et al. 2008, simplified; black shale intervals after Feldman-Olszewska 2005)

2004). It overlies the Lower Bajocian (sauzei-humphriesianum zones) sandy Kościelisko Beds (Fig. 2a), resting with a stratigraphic gap on older Mesozoic rocks (Kopik 1997, 1998). Upwards, it passes into condensed Callovian deposits, overlain by Oxfordian limestone. The ore-bearing clay reaches its maximum thickness of about $200 \mathrm{~m}$ north 


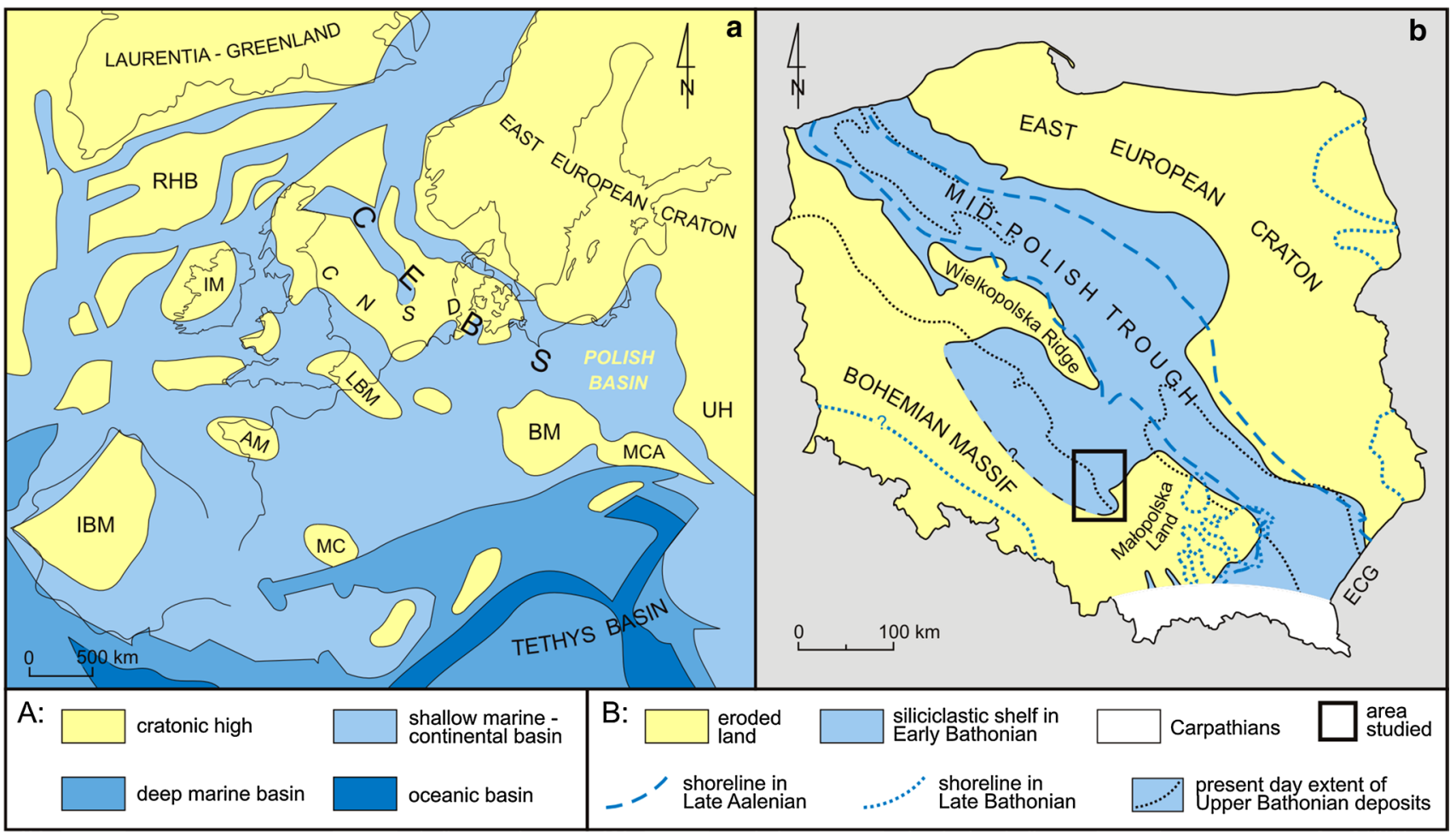

Fig. 3 a Paleogeographical map of Europe in the Middle Jurassic (after Ziegler 1990, modified). b Polish Basin in the Middle Jurassic (after Feldman-Olszewska 1998, modified) and the location of the area studied. AM Armorican Massif, BM Bohemian Massif, $C E B S$
Central European Basin System, CNSD Central North Sea Dome, $E C G$ East European Gate, IBM Iberian Meseta, IM Irish Massif, $L B M$ London-Brabant Massif, $M C$ Massif Central High, $M C A$ Meta-Carpathian Arc, $R H B$ Rockall-Hatton Bank, $U H$ Ukrainian High of Częstochowa (Kopik 1997). To the south, its thickness decreases and south of Ogrodzieniec it wedges out, passing into other Middle Jurassic siliciclastic and calcareous rocks (Kopik 1997, 1998). The area studied is situated between Częstochowa and Ogrodzieniec (Fig. 1a), where the orebearing clay is exposed in several clay pits and drilled through by many boreholes.

\section{Paleogeography}

Middle Jurassic deposits of Poland accumulated in a semienclosed basin of an epicontinental sea, called the Polish Basin, which was the easternmost arm of the Central European Basin System (CEBS), covering the area of central Europe in the Mesozoic (Fig. 3a). The Polish Basin was bordered to the south, east, and northeast by land, whereas to the northwest, west and southeast, it connected with the CEBS and Tethys (Dadlez 1989; Feldman-Olszewska 1997). The location of its southwestern boundary is still problematic because of the erosional nature of the presentday boundary of the Jurassic deposits. It is usually assumed that the Polish Basin was bordered in the Middle Jurassic by the Bohemian Massif, which was a land area subjected to erosion (Dayczak-Calikowska and Moryc 1988; Dadlez
1989; Feldman-Olszewska 1997, 1998). This assumption is based on the almost complete lack of Middle Jurassic deposits, removed in this region by Late Cretaceous-Cenozoic erosion (Pieńkowski et al. 2008). However, it is possible that, at least from the beginning of the Bathonian, this area was covered by sea (Dadlez and Kopik 1975).

The communication of the Polish Basin with the CEBS during the Middle Jurassic was impeded by the uplift of the Central North Sea Dome (Ziegler 1990) and sedimentation in the former was governed mainly by the Tethyan regime (Pieńkowski et al. 2008). The Middle Jurassic was a time of progressive transgression, recorded by eight depositional sequences, distinguished in the thickest and most complete succession from central Poland (Pieńkowski et al. 2008). For the first time the sea entered the Polish Basin in the Aalenian, probably from the southeast through the East Carpathian Gate (Dayczak-Calikowska 1997), although the western direction from the CEBS has been postulated (Świdrowska 1994). In the beginning, sedimentation developed only in a narrow, NW-SE-oriented axial zone called the Mid-Polish Trough (MPT, Fig. 3b), which was characterized by the strongest subsidence. During the Bajocian and Bathonian, the sea extended to the northeast and southwest from the MPT and this resulted in the onlap of Middle 
Jurassic deposits on older Mesozoic rocks. The maximum extension of the sea occurred during Late Bathonian, when it covered almost all the Polish Lowlands (Fig. 3b). In the Callovian, the Polish Basin underwent a reorganization of its structural pattern and finally in the Late Jurassic it became part of the northern shelf of Tethys (Kutek 1994; Matyja and Wierzbowski 2006a).

The Middle Jurassic succession consists mostly of various siliciclastic rocks, ranging from claystone to conglomerate, with only subordinate carbonate. According to Feldman-Olszewska $(2005,2007,2008,2012)$, the black shale was deposited in the Polish Basin during three periods: (1) Late Aalenian-Early Bajocian, when sedimentation was restricted to the MPT, (2) Late Bajocian, when it extended into the Silesian-Kraków region, and (3) Early Bathonian, when it reached its widest extent in the Polish Basin (Fig. 2b). The thickness of the whole Middle Jurassic succession in the MPT exceeds $1000 \mathrm{~m}$, whereas outside this zone it decreases below $300 \mathrm{~m}$, as a result of reduced subsidence and the occurrence of several hiatuses in its lower part (Dayczak-Calikowska and Moryc 1988; FeldmanOlszewska 1997; Pieńkowski et al. 2008).

The Silesian-Kraków area was situated in the southern part of the Polish Basin, bordered from the south by the Małopolska Land (Fig. 3b). For the first time, the sea covered this region in the Early Bajocian (sauzei-humphriesianum chrons: Kopik 1998) and this is recorded by sandstone and heterolithics with a marine fauna referred to as the Kościelisko Beds. After the regression in the subfurcatum chron, the sea returned to the Silesian-Kraków region in the garantiana chron, marking the onset of deposition of the Częstochowa Ore-Bearing Clay Formation (Kopik 1998). Marine sedimentation lasted here until the end of the Jurassic, although the transgression was interrupted by several regressions and stillstands.

\section{Characteristics of the Czestochowa Ore-Bearing Clay Formation}

The Częstochowa Ore-Bearing Clay Formation consists of dark-grey, calcareous mudstone with several horizons of siderite and calcareous concretions and clayey siderite beds. The mudstone has significant contents of quartz sand (2.5-40\%), silt (26-53\%), and shell debris (Leonowicz 2015a) and is enriched in organic matter, the total content (TOC) of which ranges from 0.8 to $2.9 \%$ (Marynowski et al. 2007; Szczepanik et al. 2007; Zatoń et al. 2012). Geochemical studies, including Rock-Eval pyrolysis and biomarker analysis, have shown that the organic matter is immature and predominantly of terrestrial origin (Marynowski et al. 2007; Szczepanik et al. 2007).
Based on sedimentological and ichnological studies, the sedimentary environment was interpreted as a lower offshore to offshore transition zone, periodically passing to a distal lower shoreface (Leonowicz 2015a, b). In a marginal part of the semi-enclosed epicontinental sea, it implies depths not exceeding several tens of meters with possible temporary shallowing to less than $20 \mathrm{~m}$ (cf. Immenhauser 2009). Such a situation is very probable, as the whole Polish Basin was relatively shallow; according to FeldmanOlszewska (2005) the depth of the MPT zone only slightly exceeded the storm wave base. Detailed sedimentological examination has shown that the sea floor was frequently affected by storm-generated bottom currents, which supplied significant amounts of sediment and reworked previously deposited material (Leonowicz 2013). Geochemical indices: $\mathrm{Th} / \mathrm{U}, \mathrm{Ni} / \mathrm{Co}, \mathrm{V} / \mathrm{Cr},(\mathrm{Cu}+\mathrm{Mo}) / \mathrm{Zn}$ ratios, degree of pyritization (DOP) and pyrite framboid diameters, as well as biomarker characteristics, point to deposition under an oxygenated, non-stratified water column, with dysoxic conditions prevailing within the sediment (Marynowski et al. 2007; Szczepanik et al. 2007; Zatoń et al. 2009). Sedimentological and ichnological studies have generally confirmed this interpretation, but revealed distinct vertical and lateral variability of the bottom-water conditions, linked with changes of oxygenation and sedimentation rate (Leonowicz 2015b). This variability is recorded by the variable diversity of the benthic fauna and trace fossil associations as well as the state of preservation of primary sedimentary structures. Based on these differences, two facies varieties, bioturbated and laminated, and eight associated ichnofacies, were distinguished (Leonowicz 2015b). Laminated deposits are the subject of the present study.

\section{Methods}

Deposits in five selected fully cored boreholes from the Częstochowa-Zawiercie area (Fig. 1a) were examined on the basis of lithology, sedimentary structures, benthic fauna, and bioturbation. Trace fossils and biodeformational structures (including mottles, homogenization, and cryptobioturbation) were distinguished (cf. Wetzel 2008; Leonowicz 2015b). Additionally, the total intensity of bioturbation was recorded, using the ichnofabric index (i.i.) scheme of Droser and Bottjer (1986). Based on these observations, five facies types were identified. Their characteristics were supplemented with data previously obtained during examination of exposures from the same area (Leonowicz 2013, $2015 \mathrm{a}, \mathrm{b})$. Stratigraphy of the studied boreholes is after Kopik (1998). 


\section{Results}

The studied succession is generally uniform as regards lithology and sedimentary structures. It consists of darkgrey mudstone and subordinate claystone, which reveal different types of parallel and lenticular lamination, disturbed by bioturbation to varying degrees. The classification applied here is based on the preservation state of primary sedimentary structures and the trace fossil and benthic faunal associations, which reflect different levels of seafloor oxygenation. Detailed characteristics of facies, including composition of trace fossil and benthic faunal associations as well as descriptions of sedimentary structures and their interpretation, are placed in Table 1. Distribution of facies in borehole and outcrop sections is shown in Fig. 4.

\section{(A) Laminated mudstone facies $\left(\mathrm{M}_{1}\right)$}

This facies type is characterized by the occurrence of wellpreserved parallel lamination (Table 1; Fig. 5a, b), undisturbed or only weakly disturbed by benthic activity. Laminae composed of silt, sand, and/or shell debris (Fig. 6a-c) are randomly dispersed in the mudstone or arranged in lamina bundles, graded rhythmites, and units showing grain-size gradation from sand to silty clay and clay (cf. Leonowicz 2013). Bioturbation intensity is sparse to low (i.i. $=2-3$ ) and diversity of the trace-fossil association is low. The complete ichnofossil association, observed in the Ogrodzieniec exposure, contains five ichnogenera (Table 1), and biodeformational structures are represented mainly by cryptobioturbation. Beside Trichichnus and pyritized burrows, which occur throughout the entire deposit, other trace fossils are associated with silt-sand laminae (Leonowicz 2013). The only common representatives of the benthic fauna are epifaunal bivalves Bositra, which occur as individual specimens and as mass occurrences on bedding planes (Fig. 6d). The shells in the latter represent different size classes, are commonly articulated, and preserved in "butterfly position", which suggest that they are preserved in situ and represent short-term benthic colonization events (Leonowicz 2013). In addition, rare infaunal bivalves belonging to families Nuculidae and Nuculanidae and small gastropods were observed.

\section{(B) Finely laminated claystone facies $\left(C_{1}\right)$}

This facies type is represented by claystone, which at first sight appears structureless. However, careful examination reveals a local fine lamination (Table 1), which suggests that the homogenous appearance does not result from a lack of primary sedimentary structures, but from poor lithological contrast, which makes them barely visible. This is supported by the strong tendency of claystone to split into thin sheets that reflect the parallel-ordered fabric of the rock. Apart from scattered Chondrites, other trace fossils were not observed, but they might be indiscernible like the fine lamination. However, taking into account the good preservation of thin laminae, which suggests sparse to low bioturbation intensity, it may be inferred that trace fossils, even if present, are uncommon. For the same reason, biodeformational structures are probably represented mainly by cryptobioturbation, which does not obliterate the subtle lamination. No benthic fauna was found.

\section{(C) Alternating laminated and bioturbated mudstone facies $\left(\mathbf{M}_{\mathbf{a}}\right)$}

This facies type consists of alternating intervals of parallel laminated and strongly bioturbated mudstone, which are $0.5-10 \mathrm{~cm}$ thick (Fig. 5c, d). Laminated intervals display the same features as facies of laminated mudstone $\left(\mathrm{M}_{1}\right)$. They have erosional bases and gradually pass upwards into bioturbated sediment, which is either homogenized or mottled and reveals moderate-to-high bioturbation intensity (i.i. $=4-5$ ). The diversity of trace fossil and benthic faunal associations is low. A complete ichnofossil association, determined in the Blanowice exposure, contains six ichnogenera (Table 1), from which only Trichichnus, pyritized burrows and Chondrites are quite common (Leonowicz 2015b). The benthic fauna, similar to that in facies $\mathrm{M}_{1}$, is not diverse. It is represented by the common epifaunal bivalve Bositra, occurring as individual specimens and mass-occurrences on bedding-planes, as well as rare infaunal bivalves Nuculids, Nuculanids, and small gastropods.

\section{(D) Homogenized mudstone facies $\left(\mathbf{M}_{\mathrm{h}}\right)$}

This facies type is represented by bioturbated mudstone, in which moderate-to-strong bioturbation (i.i. $=4-5$ ) led to almost complete homogenization of the sediment (Fig. 5e). However, some relicts of primary sedimentary structures, similar to these observed in facies $\mathrm{M}_{1}$, are still present (Table 1). The diversity of the trace-fossil association in this facies varies from low to moderate. The most complete ichnofossil association, observed in clay pits from Częstochowa, includes common Chondrites, Trichichnus, and pyritized burrows as well as seven other, less common ichnogenera (Table 1; Leonowicz 2015b). Biodeformational structures are hardly discernible, but are documented by homogenization of the sediment. The benthic fauna is common and diverse. It is represented mainly by various infaunal and epifaunal bivalves of different sizes as well as brachiopods, gastropods, scaphopods, foraminifers, and echinoderms (Table 1; cf. Gedl et al. 2012). 


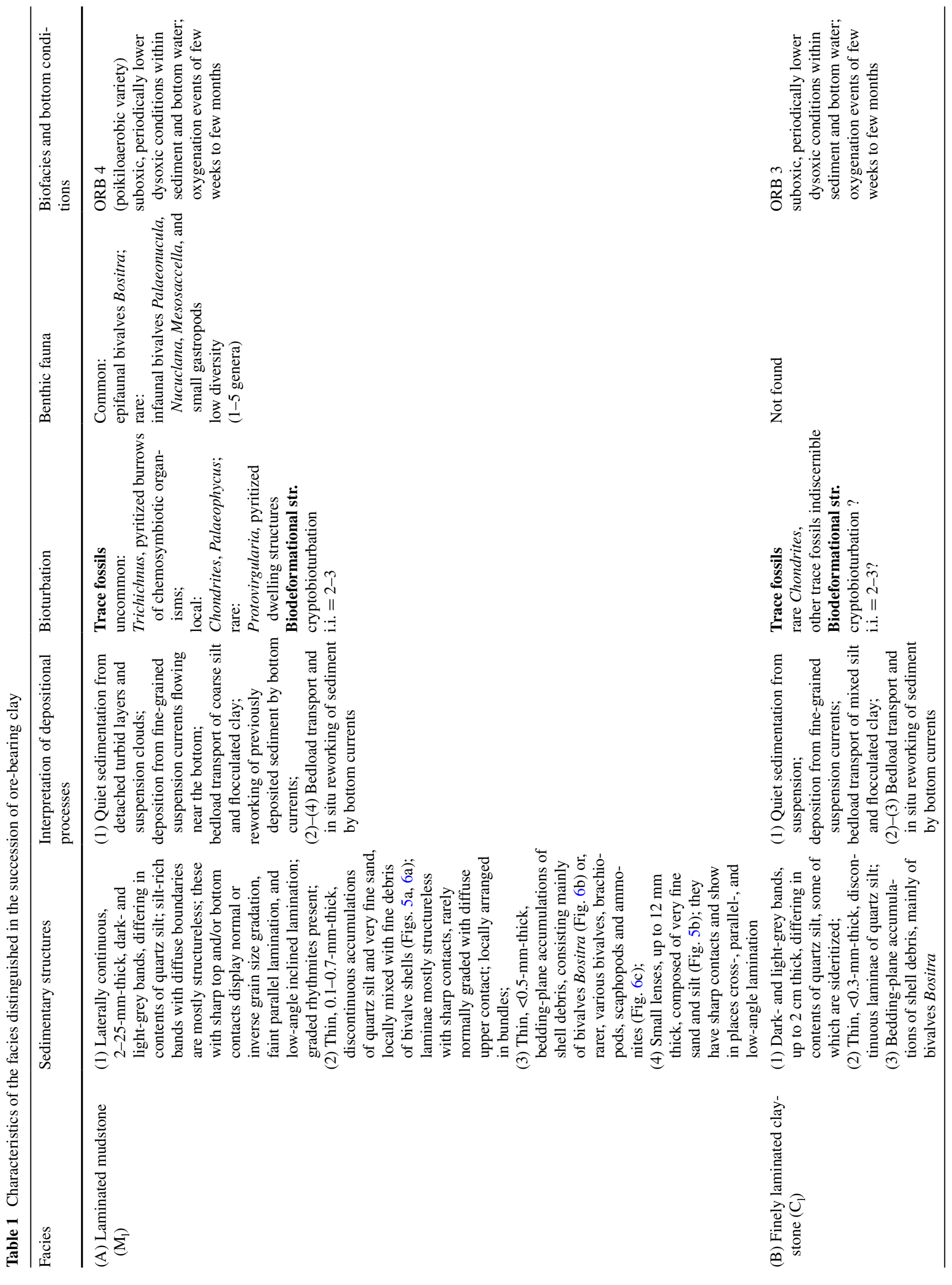




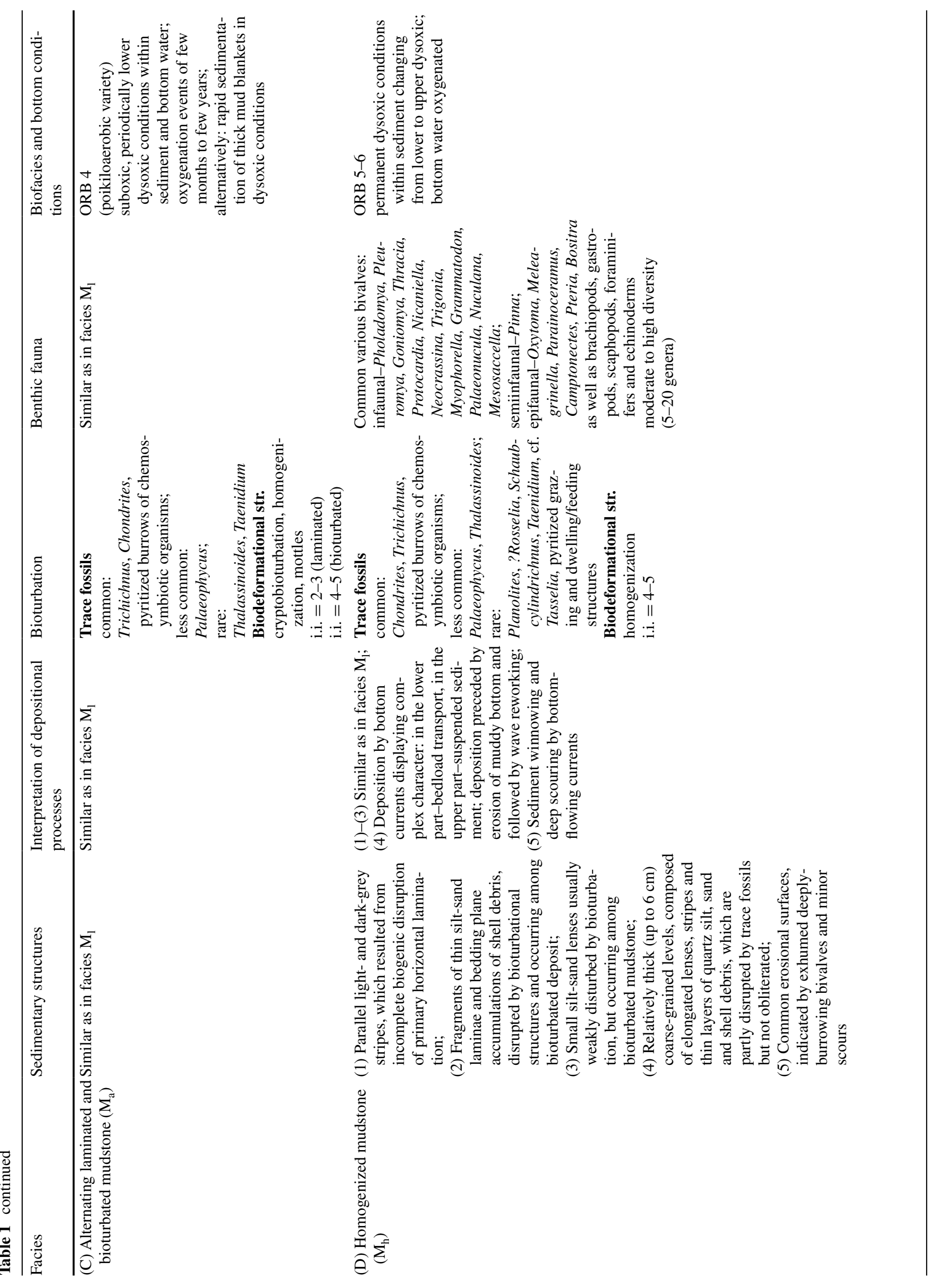




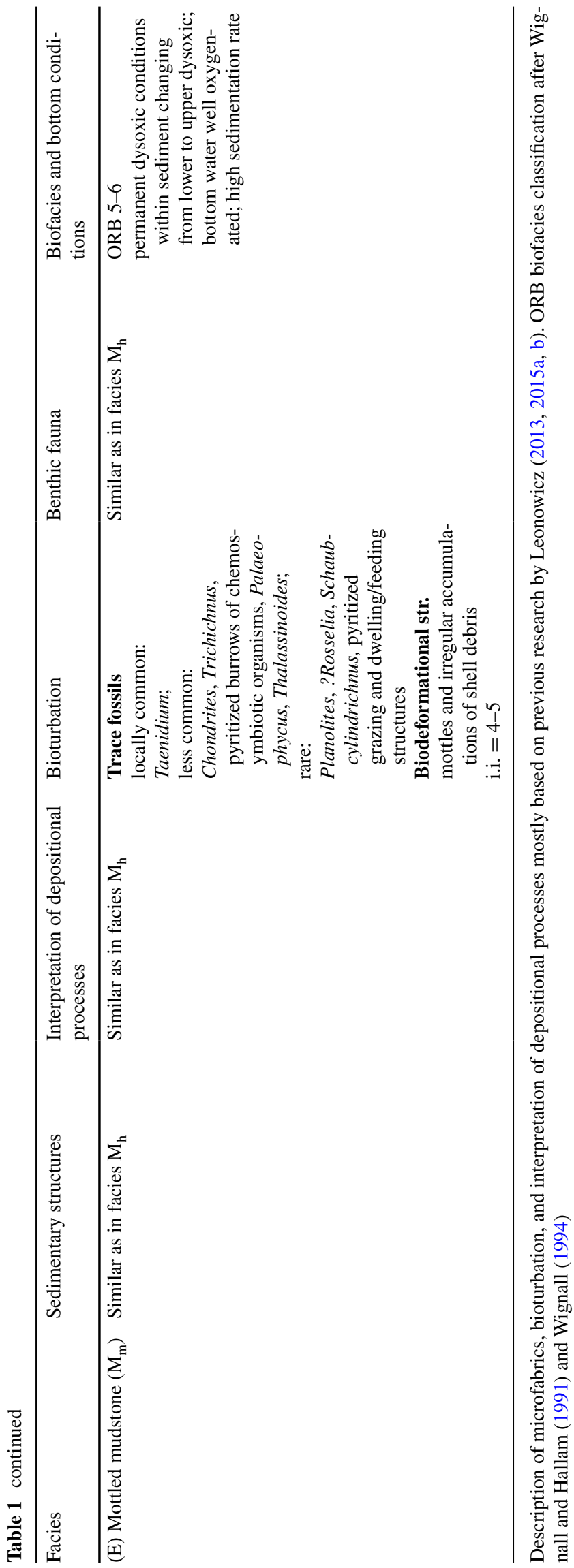

\section{(E) Mottled mudstone facies $\left(M_{m}\right)$}

This facies type consists of strongly bioturbated mudstone, in which the most characteristic components of the ichnofabric are large, well-discernible biodeformational structures, represented by mottles, and irregular, elongated accumulations of shell debris and small shells (Fig. 5f). Despite strong bioturbation, mudstone reveals in places relicts of sedimentary structures, similar to those observed in facies $M_{h}$. Bioturbation intensity is moderate to high (i.i. $=4-5$ ) and the diversity of the trace-fossil association is moderate. The most complete ichnofossil association was observed in exposures from Częstochowa and included nine ichnogenera (Table 1; Leonowicz 2015b). Beside Taenidium, which is common in some intervals, other trace fossils are rare and scattered in the mudstone. The benthic fauna, similar to that in facies $\mathrm{M}_{\mathrm{h}}$, is common and diverse.

\section{Spatial facies distribution}

\section{Vertical succession}

Facies distribution analysis based on core correlation revealed some regularity in the vertical succession of facies (Fig. 4). The ore-bearing clay starts predominantly with finely laminated claystone $\mathrm{C}_{1}$, which is up to $15 \mathrm{~m}$ thick and overlies shallow-marine sandstone. In some places, it is underlain by a 1-2-m-thick package of alternating laminated and bioturbated mudstone $\mathrm{M}_{\mathrm{a}}$ and/or bioturbated mudstone $\mathrm{M}_{\mathrm{h}}$ and $\mathrm{M}_{\mathrm{m}}$ (Biskupice 25BN and Piaseczno 60BN boreholes). Upwards, finely laminated claystone passes into laminated sediments of facies $\mathrm{M}_{1}$ and $\mathrm{M}_{\mathrm{a}}$, which in the southern part of region are 30-53 m thick and occupy half or more of the succession. The upper part of the formation consists mostly of bioturbated deposits of facies $\mathrm{M}_{\mathrm{h}}$ and $\mathrm{M}_{\mathrm{m}}$. Only in the northern part of the studied area is finely laminated claystone overlain directly by bioturbated deposits, which constitute the main part of the sections, occupying intervals upto $126 \mathrm{~m}$ thick.

\section{Lateral facies distribution}

Laminated deposits of facies $C_{1}, M_{1}$, and $M_{a}$ pass southwards into shallower-water, sandy and calcareous sediments, displaying strong condensation and common hiatuses (Fig. 7). Such deposits consisting of clayey sandstone and sandy limestone with large, encrusted oncoids and stromatolite-like crusts, crop out in Blanowice and Ogrodzieniec and were previously described by Zatoń et al. (2012). In the Piaseczno 60BN borehole, they are represented by the uppermost part of a sandy complex, underlying the ore-bearing clay (Fig. 4). Towards the north, laminated deposits pass into bioturbated mudstone of facies $M_{h}$ 
and $\mathrm{M}_{\mathrm{m}}$ (Fig. 7). During the Late Bajocian and Bathonian, facies zones shifted towards the south but their succession did not change.

\section{Discussion}

\section{Sedimentary environment}

Depositional processes and seafloor oxygenation during sedimentation of the ore-bearing clay were previously studied by Leonowicz (2013, 2015a, b). Characteristics of silt-sand and shell debris laminae, combined with their random distribution in the section as well as the semienclosed, epicontinental character of the Polish Basin, suggest they are storm-event deposits, with sediment brought from shallower parts of the basin by storm-induced bottom flows (Leonowicz 2013, 2015a). The coarser-grained material was carried together with mud in the form of finegrained suspension flows and fluid mud layers, in which the upper portion was transported as a suspension and the lower one as bedload (Leonowicz 2013). Deposition from suspension is suggested by several structures: laminae with erosional bases and gradational tops, normal grading, fine parallel lamination, and graded rhythmites. Bedload transport is indicated by the occurrence of small sand-silt lenses, which reveal cross-lamination and low-angle lamination. Erosion of the sea floor and reworking of previously deposited sediment, which accompanied deposition of event laminae, are recorded by inversely graded siltsand laminae, laminae with sharp upper contacts, exhumed deeply burrowing bivalves and minor scours (Leonowicz 2013, 2015a).

Storm-event laminae are common in facies $\mathrm{M}_{1}, \mathrm{M}_{\mathrm{a}}$, and $\mathrm{C}_{1}$, although in the latter they are hardly visible due to the poor lithological contrast. The relicts of such laminae were also commonly observed in bioturbated mudstone of facies $\mathrm{M}_{\mathrm{h}}$ and $\mathrm{M}_{\mathrm{m}}$, suggesting similar depositional processes (cf. Leonowicz 2015a). This indicates that both laminated and bioturbated mudstone originated in a relatively high-energy environment, frequently affected by bottom currents. In the case of facies $\mathrm{M}_{\mathrm{m}}$, the domination of biodeformational structures and irregular, patchy distribution of other ichnofossils point to an increased sedimentation rate (Leonowicz 2015b; cf. Wetzel 1991b; Wetzel and Uchman 1998). The scarcity of sedimentary structures of possible wave origin suggests that the sea floor was mostly below storm wave base and only exceptionally within the range of storm or even fair-weather waves. However, as noted in an earlier section, the depth of the basin was probably not more than several tens of meters (Leonowicz 2015a). The relatively shallow-water location is also suggested by the vicinity of Małopolska Land.

\section{Seafloor oxygenation}

Seafloor oxygenation changed within the succession from suboxic to moderate dysoxic (cf. Leonowicz 2013, 2015b). Composition of the trace-fossil and benthic faunal associations in facies types $\mathrm{M}_{1}, \mathrm{C}_{1}$, and $\mathrm{M}_{\mathrm{a}}$, which are dominated by forms tolerant of low oxygen levels (Trichichnus, Chondrites, pyritized burrows of chemosymbiotic animals, bivalve Bositra), point to suboxic conditions prevailing within the sediment and on the sea floor, which frequently changed to lower dysoxic. Suboxic conditions are recorded by intervals displaying a sparse bioturbation intensity, common cryptobioturbation, and the trace fossil association containing Trichichnus and pyritized burrows. The appearance of other ichnofossils, stronger bioturbation, and mass-occurrences of Bositra, reflects periods of re-oxygenation, during which dysoxic conditions developed. Depending on the duration of re-oxygenation periods, which could have lasted from a few weeks to a few years (see "Black shale origin" below), they led to the development of thin (few mm thick), bioturbated laminae occurring in facies $M_{1}$ and $C_{1}$, or relatively thick (up to $10 \mathrm{~cm}$ thick), homogenized and mottled intervals with a tiered ichnofabric, which were observed in facies $M_{a}$. In the case of mass occurrences of Bositra, the additional factor facilitating their settling could be the occurrence of coarser-grained accumulations on the sea floor, which served as a more stable substrate, although this bivalve can easily live directly on the soft mud thanks to its flat, thin valves (cf. Wignall 1994).

Facies types $\mathrm{M}_{\mathrm{h}}$ and $\mathrm{M}_{\mathrm{m}}$ are characterized by moderateto-strong bioturbation of sediment, higher diversity of trace fossils, as well as a common and diverse benthic fauna, which point to a better oxygenation of the sea floor compared to laminated deposits. Their characteristics point to well-oxygenated bottom water and lower dysoxic conditions prevailing within the sediment, in which producers of Chondrites, Trichichnus, and pyritized burrows dominated (cf. Leonowicz 2015b). Other trace fossils originated during periods with increased oxygen availability in the sediment (moderate dysoxic level), enabling more demanding animals to live there. Depending on the degree of oxygenation and its duration, the shallow tier of ichnofabric and the benthic faunal suite were less or more diverse. Dysoxic conditions could also prevail during deposition of laminated-bioturbated couplets from facies $\mathrm{M}_{\mathrm{a}}$, which appear within the generally bioturbated succession. They likely resulted from episodic deposition of thick portions of mud, the lower part of which was prevented from bioturbation by a substantial thickness of rapidly deposited sediment (Leonowicz 2015b).

The characteristic features of facies types $M_{1}, M_{a}$, and $\mathrm{C}_{\mathrm{l}}$, pointing to deposition in an oxygen-deficient, 


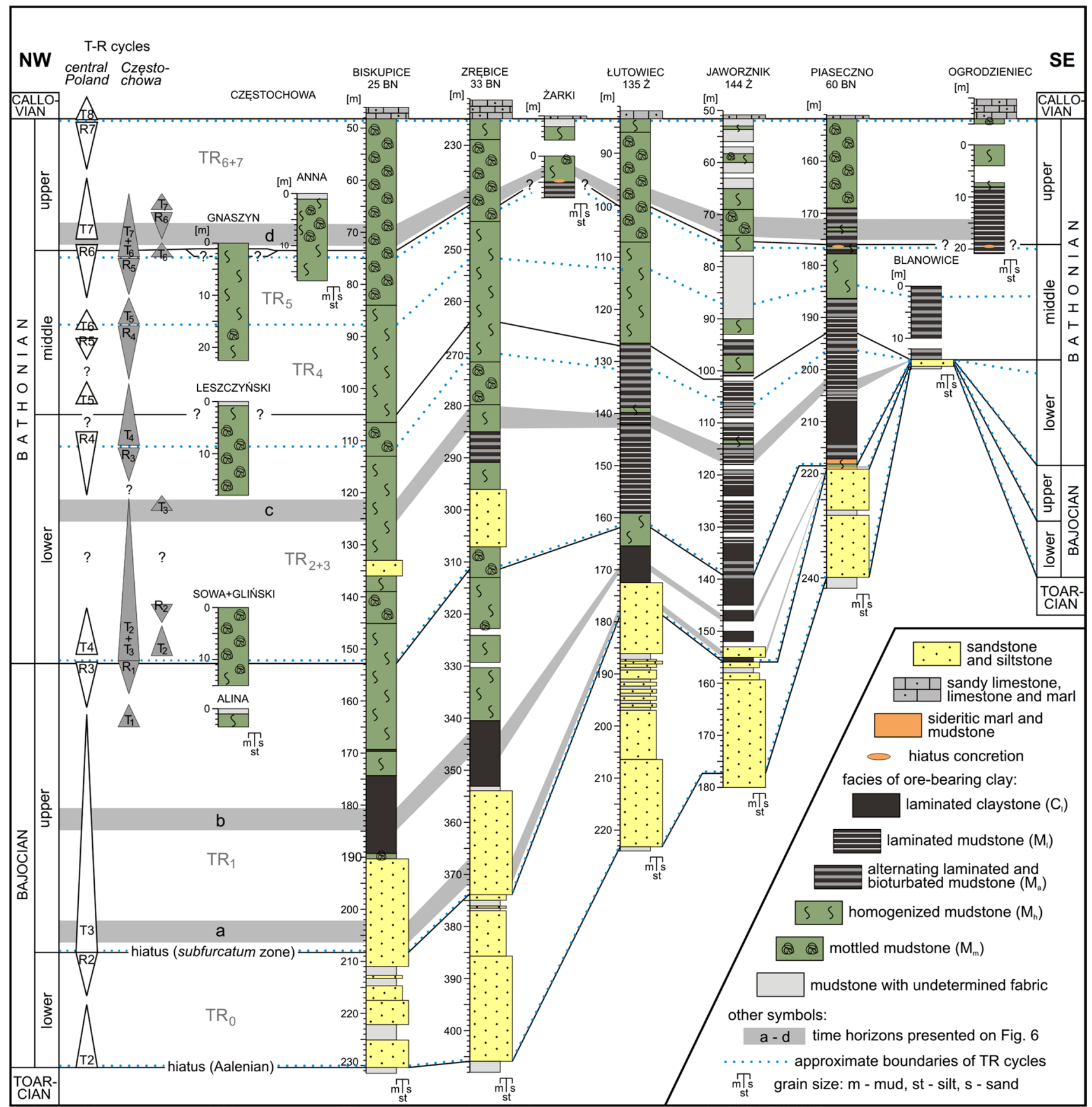

Fig. 4 Representative logs of Middle Jurassic deposits from the Częstochowa-Zawiercie region. T-R cycles from central Poland after Pienkowski et al. (2008), T-R cycles from Częstochowa after Leono- wicz (2015a). Biostratigraphy after Kopik (1998), Matyja and Wierzbowski (2000, 2003, 2006b), Zatoń (2007) and Zatoń et al. (2011, 2012). For localities see Fig. 1 suboxic to lower dysoxic environment, combined with an increased content of organic carbon in the entire orebearing clay succession, are typical of black shale. The two other facies types, $M_{h}$ and $M_{m}$, representing darkgrey bioturbated mudstone (sensu Sageman et al. 1991), originated in less restrictive, although still dysoxic conditions.

\section{Black shale occurrence within the depositional sequence}

The black shale described here is a part of a succession that records a gradual transgression of the Middle Jurassic sea across the Silesian-Kraków region and therefore it can be regarded as an example of a transgressive black shale. 

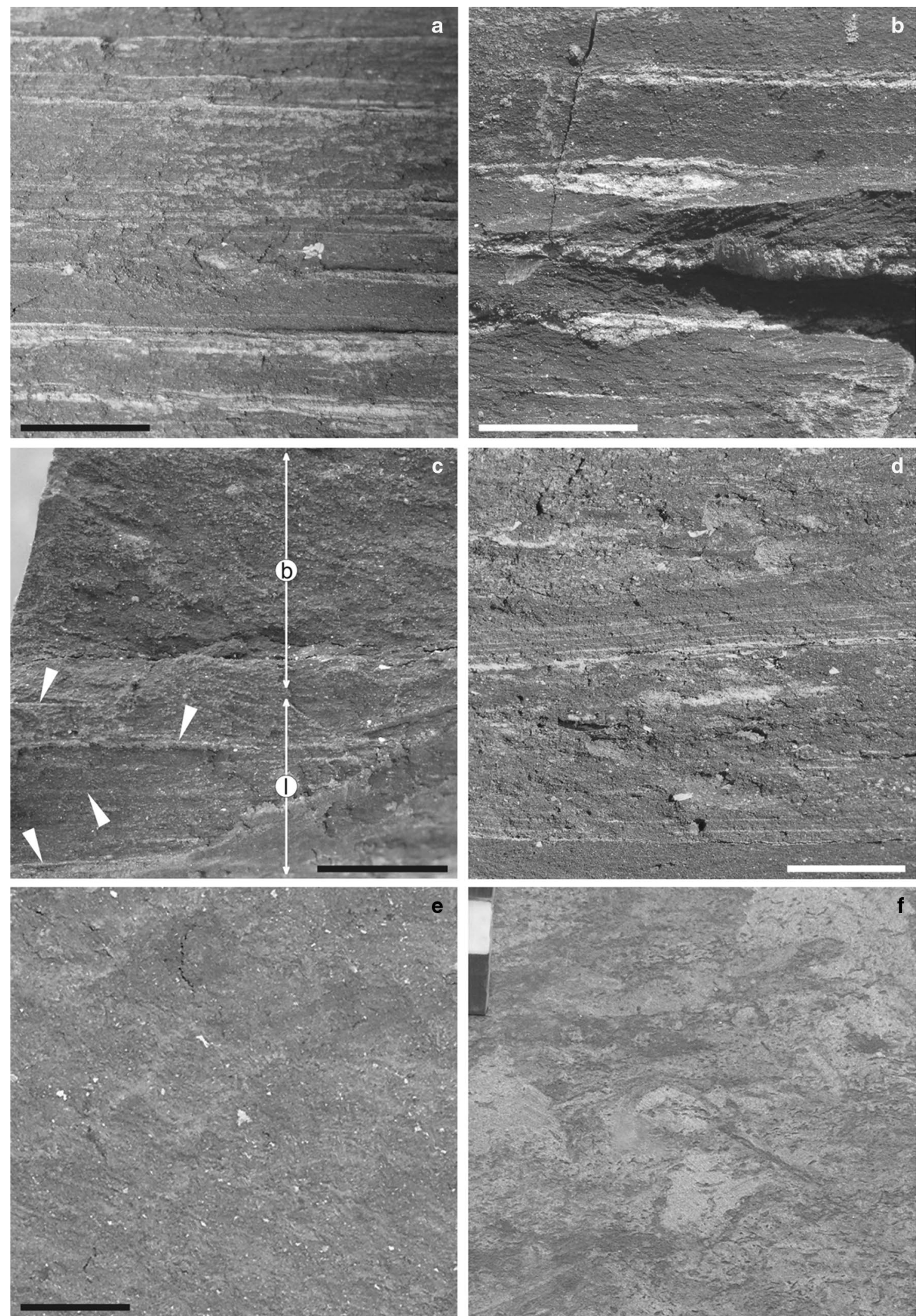
4 Fig. 5 Facies types from the ore-bearing clay. a, b laminated mudstone $\left(\mathrm{M}_{1}\right)$ : a thin silt laminae (in the upper half of the picture) and two lamina bundles (in the lower half); b small silt-sand lenses; c, d alternating laminated and bioturbated mudstone $\left(\mathrm{M}_{\mathrm{a}}\right)$ : c laminated (1)-bioturbated (b) couplet, in which bioturbated part is completely homogenized. In the lower half of the image fine silt laminae are indicated by arrows; $\mathbf{d}$ two couplets in which bioturbated parts are mottled. Sharp erosional bases of couplets and gradual transition from laminated to bioturbated sediment are visible; e homogenized mudstone $\left(\mathrm{M}_{\mathrm{h}}\right)$; f mottled mudstone $\left(\mathrm{M}_{\mathrm{m}}\right)$. Vertical sections. Scale bar in $\mathbf{a}-\mathbf{e}$ is $1 \mathrm{~cm}$, in $\mathbf{f}$ is in centimeters; $\mathbf{a}, \mathbf{b}$ Ogrodzieniec clay pit, c Blanowice clay pit, d Żarki clay pit, e Gnaszyn clay pit (Częstochowa), f Biskupice 25BN borehole (depth $66.5 \mathrm{~m}$ )

During this transgression, the shoreline shifted southwards, and this is recorded by the gradual thickness reduction of Bajocian and Lower Bathonian deposits and the onlap of ore-bearing clay on the underlying sandstone (Fig. 4).
South of Ogrodzieniec, where the ore-bearing clay disappears, the transgression is recorded by a littoral Parcze conglomerate and Balin oolite, both of Late Bathonian age, lying directly on Triassic deposits (Kopik 1997). Farther to the south, in the Kraków region, the Middle Jurassic is represented by the limnic Grojec clay, also of Bathonian age (Marcinkiewicz 1980).

As mentioned in the introduction, black shale occurs usually in two positions within the transgressive systems tract: at the base, resting on a transgressive surface, and around the maximum flooding surface, marking peak transgression or the early stage of the highstand (Wignall 1994). The sequence stratigraphy for the succession from the Częstochowa-Zawiercie region has not yet been unraveled, which makes precise correlation of the studied black shale with the depositional sequences impossible. However,
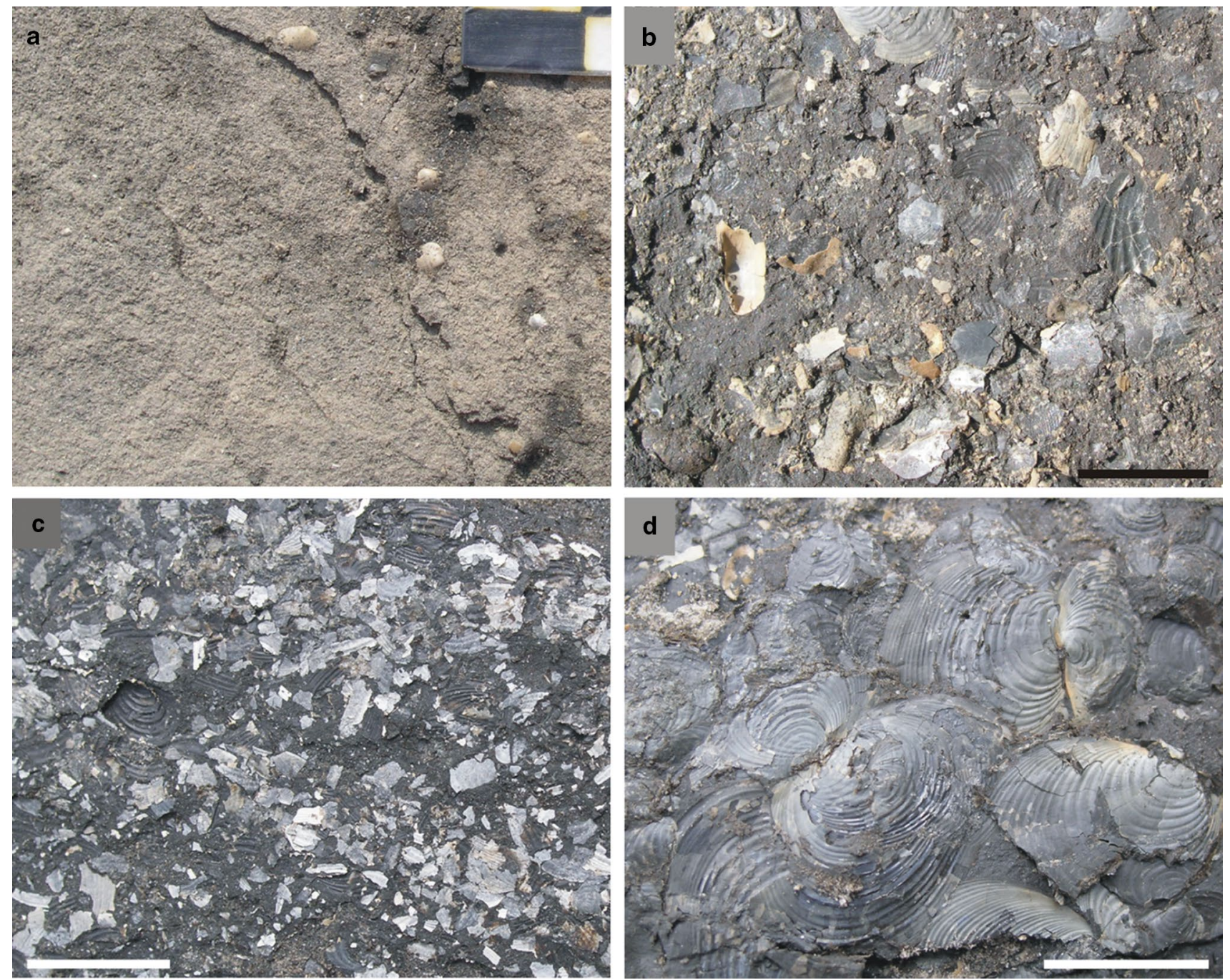

Fig. 6 Composition of event laminae from ore-bearing clays. a Accumulation of quartz silt and very fine sand with a few disarticushells of various bivalves. c Accumulation of fragmented shells of bivalve Bositra. d Bedding plane covered in Bositra shells, which are mostly articulated and preserved in a "butterfly position" 


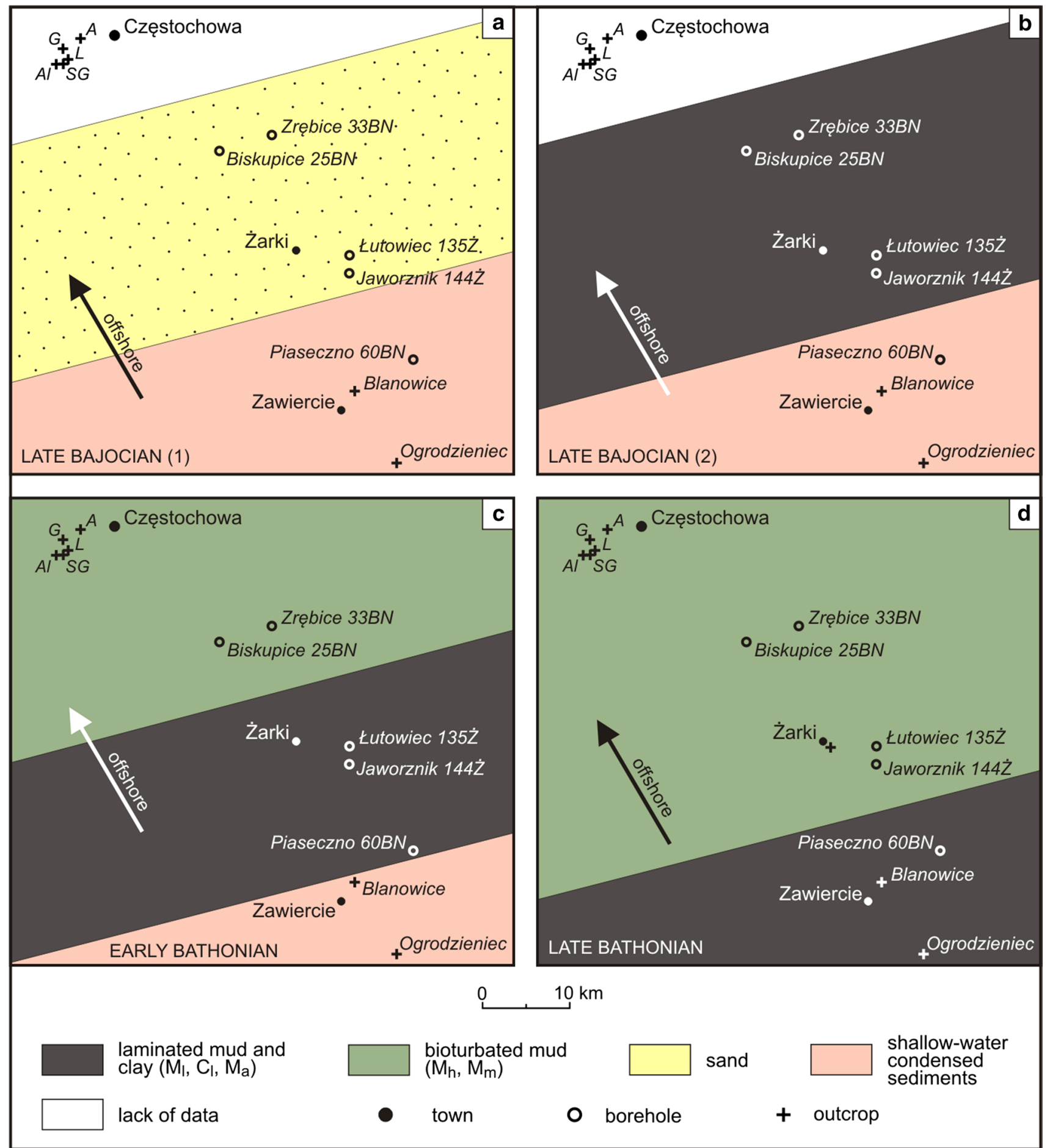

Fig. 7 Paleogeographical maps of the Częstochowa-Zawiercie region showing spatial development of sedimentation during the Middle Jurassic transgression. a Late Bajocian (1): sedimentation of marine sand prevails in the area studied; in the Zawiercie region, the deposit is strongly condensed; b Late Bajocian (2): in the middle part of the study area, deposition of black shale begins; to the south it passes into a condensed deposit; c Early Bathonian: the black shale zone shifts to the south; in the northern part of the area, bioturbated mud occurs; d Late Bathonian: black shale accumulates only in the Zawiercie region; in the rest of the area studied, bioturbated mud prevails. Presented time horizons are marked in Fig. 4. Clay pits in Częstochowa: A Anna, Al Alina, $G$ Gnaszyn, $L$ Leszczyński, $S G$ Sowa-Gliński 
for the purpose of this study, the approximate boundaries of transgressive-regressive (TR) cycles were determined (Fig. 4) based on the scheme worked out for the succession from Częstochowa (Leonowicz 2015a) and the correlation with TR cycles distinguished in the succession from central Poland (Pieńkowski et al. 2008). The numbering of the cycles is consistent with the scheme proposed for the Częstochowa section.

The basal transgressive surface occurs at the base of a thick sandstone complex of Bajocian age (Fig. 4), which overlies either an alluvial sandstone of the Upper Toarcian Borucice Formation or a marine mudstone of the Lower Toarcian Ciechocinek Formation (Kopik 1998). This complex is divided into two parts by a poorly developed and not always identifiable hiatus horizon, linked with a marine regression in the subfurcatum chron (Kopik 1998). The lower part, dated as Early Bajocian, is referred to as the Kościelisko Beds (Kopik 1998) and constitutes the oldest cycle $\mathrm{TR}_{0}$, correlating with cycle TR2 from central Poland (Pieńkowski et al. 2008). The upper complex is of Late Bajocian age (Kopik 1998) and commences the next cycle $\mathrm{TR}_{1}$, during which sedimentation of the ore-bearing clay began. In the Częstochowa and Żarki regions, sedimentation of mud started in the middle Late Bajocian, during the cycle $\mathrm{TR}_{1}$ (Fig. 4). North of the Zawiercie area (Piaseczno $60 \mathrm{BN}$ ) it began in the Early Bathonian, during cycle $\mathrm{TR}_{2+3}$ and spread out towards Blanowice and Ogrodzieniec in the Middle Bathonian (cycle $\mathrm{TR}_{4}$ ).

The black shale occurs mainly in the lower half of the ore-bearing clay succession (Fig. 4), overlying directly shallower-marine sandstone; it is much more common in sections from proximal locations, in which it constitutes more than half of the sequence (Jaworznik 144Ż, Piaseczno 60BN, Blanowice, and Ogrodzieniec). The correlation of black shale with particular TR cycles is not evident. In the proximal locations, it commonly occupies intervals corresponding to whole cycles $\left(\mathrm{TR}_{1}\right.$ cycle in Jaworznik $144 \dot{Z}, T_{2+3}$ cycle in Łutowiec $135 \dot{Z}$, Jaworznik $144 \dot{Z}$ and Piaseczno 60BN, $\mathrm{TR}_{4}$ cycle in Blanowice). Along with increasing distance from the shoreline, i.e., laterally towards the north and upwards in each section, the laminated facies disappears gradually from the upper part of TR cycles $\left(\mathrm{TR}_{1}\right.$ cycle in Biskupice $25 \mathrm{BN}$, Zrębice 33BN and Łutowiec 135Ż, $\mathrm{TR}_{4}$ cycle in Łutowiec $135 \dot{Z}$ and Piaseczno 60BN, $\mathrm{TR}_{6+7}$ cycle in Piaseczno 60BN and Ogrodzieniec) and in the uppermost part of the ore-bearing clay succession only bioturbated mudstone occurs. Such features indicate that formation of black shale was generally associated with the early phase of the Middle Jurassic transgression and was favored by the proximity of the land. The second-order fluctuation of the shoreline was probably responsible for the appearance of an isolated black shale interval in the middle part of the Zrębice 33BN section, as well as an alternation of laminated and bioturbated intervals in sections Łutowiec 135Ż, Jaworznik 144Ż and Piaseczno 60BN, which, however, do not display any apparent regularity.

\section{Black shale origin}

The origin of black shale in epicontinental basins has been widely discussed by many authors, who proposed various hypotheses and models to explain the development of anoxia on the sea floor (Fig. 8). The "silled-basin" concept (Fig. 8a), based on circulation in the modern Black Sea, applies to a sea separated from the open ocean by a topographic barrier, which limits water exchange, leading to restriction of vertical mixing and development of anoxia beneath a permanent halocline (Demaison and Moore 1980). This effect may be strengthened during periods of wet and warm climate, when the high freshwater flux leads to deepening of the halocline, preventing water column mixing even if free exchange with the ocean is possible during a sea-level rise (McArthur et al. 2008; Fig. 8b).

In modern oceans, anoxia develops preferentially in upwelling zones, such as off Namibia and Peru, where deep, nutrient-rich water rises towards the surface, causing increased organic productivity and high oxygen demand on the shelf (Demaison and Moore 1980; Fig. 8c). Oxygen-deficient conditions may develop in places, where the mid-water oxygen minimum zone (OMZ), resulting from decay of organic matter settling through the water column, intersects with the continental slope (Demaison and Moore 1980; Fig. 8d). The concept of the OMZ was used to explain black shale deposition in extensive shelf seas during Jurassic and Cretaceous anoxic events in Europe (Jenkyns 1985, 1988; Jenkyns et al. 2001). According to this, high organic productivity on the shelf, flooded during the sea-level rise, was triggered by increased nutrient supply from the land and resulted in development of anoxia over a wide area of shallow epicontinental sea (Fig. 8e). Alternatively, development of the OMZ on the shelf might have been caused by enhanced preservation of organic matter beneath the halocline, which formed due to the high freshwater influx (Jenkyns 1985; Fig. 8f).

The "irregular bottom topography" ("puddle") model (Fig. 8g) proposes formation of stagnant water pockets in topographic hollows on the sea floor, in which anoxic conditions develop (Hallam and Bradshaw 1979; Wignall 1991). Such a situation is favored by fast sea-level rise during an early phase of transgression. Wignall (1991) has extended the "puddle" concept in an "expanding puddle" model (Fig. 8h), which explains the onlap of black shale on shallow-water deposits by onshore expansion of an anoxic "puddle" during the development of transgression. 

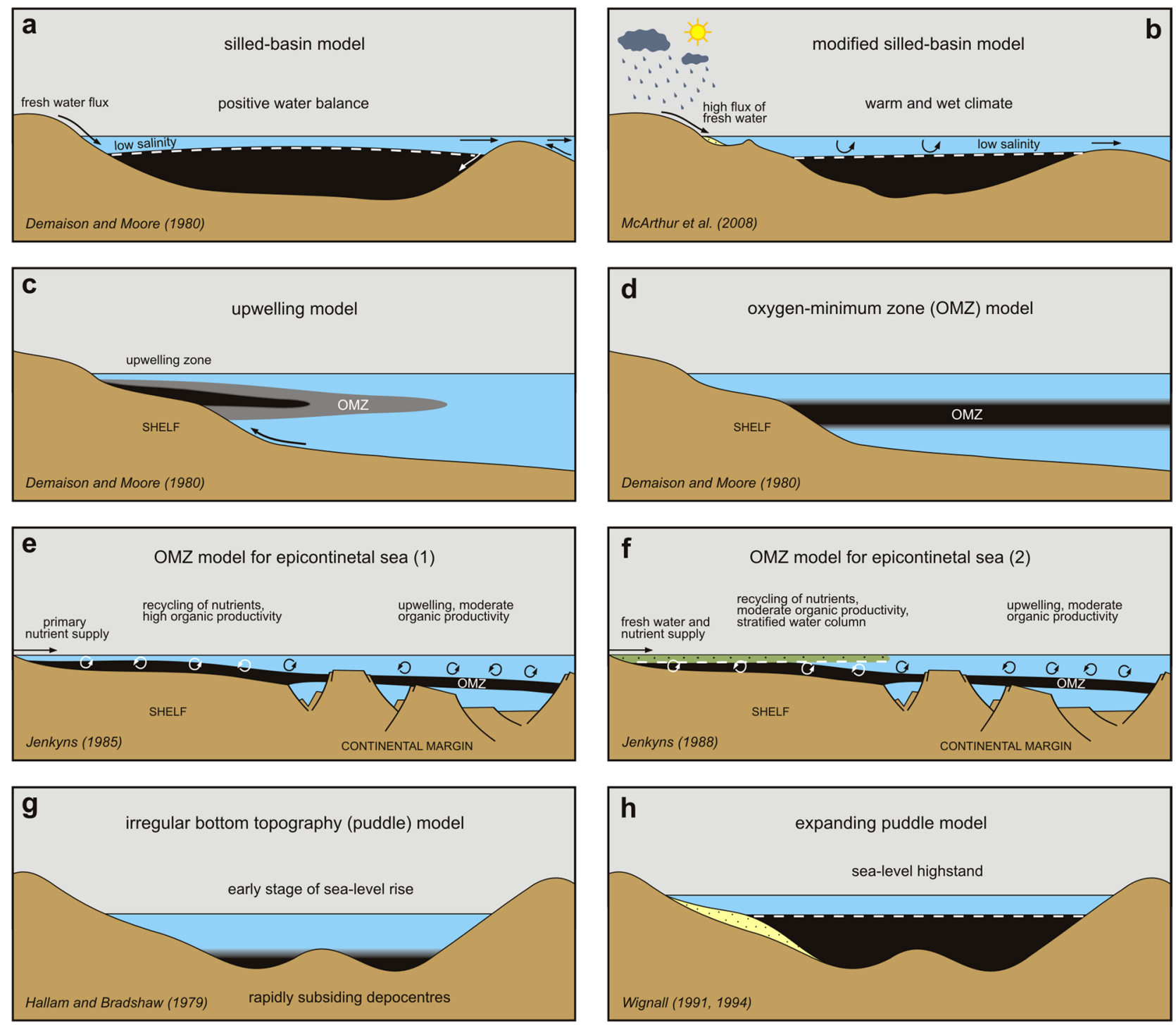

shallow-water black shale:
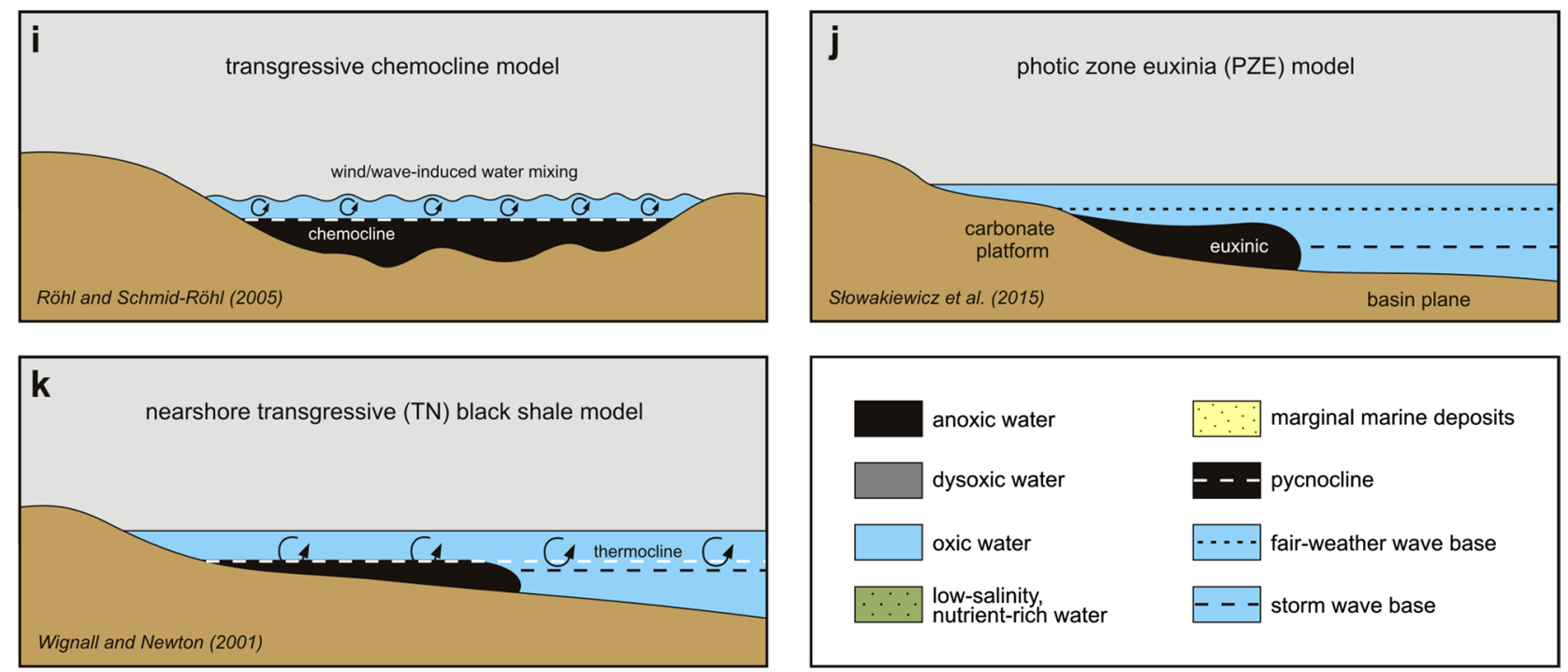
4Fig. 8 Models of black shale formation in epicontinental basins. a The "silled-basin" model for a sea separated from the open ocean by a topographic barrier. b Modified "silled-basin" model emphasizing the influence of a wet and warm climate. c Upwelling model, in which development of anoxia on a shelf is caused by upwelling of nutrient-rich water. d The "oxygen-minimum zone (OMZ)" model, in which an open ocean anoxic layer intersects with the continental slope. e Model of an OMZ in a shelf sea; the anoxia results from a high organic productivity, caused by increased nutrient supply during the marine transgression across a shelf. $\mathbf{f}$ Alternative model for the OMZ in a shelf sea; the anoxia develops due to enhanced organic matter preservation below the halocline. g The "irregular bottom topography" ("puddle") model postulating formation of stagnant water pockets in topographic hollows on the sea floor. $\mathbf{h}$ The "expanding puddle" model, in which the anoxic "puddle" expands onshore during the development of transgression. $\mathbf{i}$ The "silled-basin transgressive chemocline" model postulates water stagnation in a silled basin during the sea-level rise, however, the slow rate of transgression causes the basin to remain shallow. $\mathbf{j}$ The "photic zone euxinia (PZE)" model proposes development of localized euxinia within the water column due to increased nutrient supply. $\mathbf{k}$ The "nearshore transgressive (TN) black shale" model, in which anoxia develops in nearshore settings, where a small volume of water is trapped beneath a thermocline

None of these concepts satisfactorily explains the origin of the black shale described here. The silled-basin model assumes prolonged stagnation of oxygen-depleted water in a deep-water environment, whereas features of the orebearing clay point to relatively shallow-water conditions and frequent re-oxygenation. In the "puddle" model, the black shale also forms beneath a permanent halocline and is the deepest-water deposit at time of its formation, with neither deeper-water nor shoreline time-equivalent facies. In contrast, the spatial arrangement of facies types from the ore-bearing clay indicates that oxygen-restricted conditions developed only in a narrow, proximal zone, separated from the shoreline by an area characterized by sediment starvation (Fig. 7). Offshore, oxygenation of the sea floor increased and laminated sediment was replaced by bioturbated mud.

The "expanding puddle" concept gives rise to a deepwater condensed deposit and links its formation with maximum transgression. Such an explanation has been invoked for the black shale from the Mid-Polish Trough, associated with a significant increase of seawater depth (FeldmanOlszewska 2005), but it is not likely for the studied black shale, which accumulated in shallow-water during the beginning of transgression.

The OMZ models based on water column oxygenation in modern oceans, which invoke upwelling and the intersection of the $\mathrm{OMZ}$ with the continental slope, are also not appropriate for the ore-bearing clay. The Polish Basin was a semi-enclosed sea, separated from the Tethys by Małopolska Land, so that a direct inflow of oxygendeficient water from the ocean was not likely. In fact, in the Late Jurassic, when the Polish Basin became part of the northern shelf of Tethys, oxygenation improved, terminating deposition of dark-colored mudstone. Also, the OMZ models invoking development of anoxia in shelf seas as a result of increased nutrient supply from the land and enhanced preservation of organic matter beneath the halocline, cannot be applied to the studied deposit. These models explain the accumulation of black shale across the shelf during maximum transgression, whereas the deposit described here formed at the beginning of transgression and only in a narrow zone close to the land.

Shallow-water black shale linked with an early phase of transgression was described by Röhl and Schmid-Röhl (2005), who explained its formation by a model of "silledbasin transgressive chemocline" (Fig. 8i). In this concept, the slow sea-level rise leads to water stagnation in a silled basin, but the reduced rate of transgression prevents the establishment of deep-water conditions. This model, however, cannot be applied to the ore-bearing clay, as it invokes oxygen depletion within the entire basin, whereas in the Silesian-Kraków region black shale was deposited only in a proximal zone.

More probable is the model of "nearshore photic zone euxinia (PZE)", proposed by Słowakiewicz et al. (2015) for Zechstein deposits from Poland (Fig. 8j). The authors postulated the development of an euxinic mid-water layer due to localized high productivity, stimulated by nutrient supply from land, but without the development of a pycnocline. The intersection of PZE with a platform margin resulted in the restricted occurrence of reducing conditions only in the slope and toe-of-slope locations. The argument against such an interpretation for the black shale described here is that there is no published data, e.g., biomarker characteristics and pyrite framboid diameters, indicating euxinia within the water column (Szczepanik 2006; Marynowski et al. 2007).

The best interpretation seems to be the concept of "nearshore transgressive black shale" (Fig. 8k), proposed by Wignall and Newton (2001), in which anoxia develops due to increased nutrient supply and high organic productivity, but only in shallow nearshore settings, where a small volume of water is trapped beneath a temporary thermocline. Kimmeridgian deposits from the Boulonnais, described by these authors, display similar features to the black shale reported here: relatively shallow-water origin, evidence of frequent re-oxygenation of the sea floor and the presence of better-oxygenated time-equivalent facies in deeper locations. The only difference is that in the succession of the Boulonnais, black shale is associated only with the basal parts of parasequences, whereas in the southern part of the Polish Basin studied here, laminated sediment also formed during regressive intervals. This points to a decisive impact of land influence on the formation of the latter. 
Wignall and Newton (2001), referring to the study of Tyson and Pearson (1991), explained the origin of nearshore black shale by the development of oxygen-deficient conditions beneath a temporary pycnocline, where the bottom water was deoxygenated due to the decay of organic matter. Observations of modern seas indicate that shallow basins are especially prone to the occurrence of oxygen-deficient conditions, because of (1) high productivity, linked with increased riverine influx of nutrients and their supply from the sea floor by frequent mixing of the water column, (2) low loss of organic matter (OM) during its relatively short settling time through the water column, and (3) high accumulation rates of sediment and its associated terrestrial OM (Tyson and Pearson 1991). On the other hand, a shallow sea floor remaining within the range of storm mixing is frequently ventilated by waves and currents that improve its oxygenation. Thus, the development of anoxia in a shallow-water environment requires stratification of the water column, at least periodically, to prevent its permanent mixing. Observations of modern shelves show that optimal conditions occur in shallow, seasonally stratified water, less than $60 \mathrm{~m}$ deep, with a layer of water trapped beneath the pycnocline less than $10 \mathrm{~m}$ thick (Tyson and Pearson 1991). The increase in depth offshore and during transgression leads to thickening of the sub-pycnocline layer that prevents its rapid deoxygenation and terminates deposition of black shale.

Depositional conditions in the area studied seem to have been favorable for the development of oxygen deficiency. During the early phase of the Middle Jurassic transgression, this area was situated in a relatively shallow, marginal part of a semi-enclosed epicontinental sea (Figs. 3b, 9). The nearby Małopolska Land was a source of terrigenous OM and nutrients, which could have triggered phytoplankton blooms. Gedl et al. (2012), who analyzed palynofacies and micropaleontological assemblages from the ore-bearing clay, described periodic blooms of opportunistic planktonic taxa resulting from the increased influx of nutrients. Although geochemical analyses indicate a subordinate content of marine $\mathrm{OM}$ in the whole Middle Jurassic succession (Marynowski et al. 2007), it should be remembered that it is more degradable than terrigenous plant material and may be under-represented in ancient deposits. Based on pyritization type in the ore-bearing clay, Szczepanik (2006) suggested that the content of marine OM in the laminated facies from Ogrodzieniec could originally have been higher than in the bioturbated mudstone from Częstochowa. This would support the supposition of increased primary productivity during black shale formation and explains its preferential deposition within the most proximal locations. The other factor likely responsible for the development of suboxia on the sea floor was the event nature of sedimentation. Rapid deposition of impermeable mud blankets prevented oxygenation of the sediment column, accelerating oxygen exhaustion and favoring preservation of OM.

The nature of the pycnocline is not evident. In modern seas, the favorable conditions for localized anoxia occur in the vicinity of river mouths, where a relatively stable and strong halocline may develop. However, more extensive anoxia is usually linked with a seasonal thermocline (Tyson and Pearson 1991). Taking into account the vicinity of Małopolska Land, the occurrence of a halocline in the area studied seems likely. On the other hand, the marine fauna (bivalves, brachiopods, rare ammonites, and belemnites), found in the nearshore Niegowonice and Parcze conglomerates (Różycki 1953), suggests normal salinity of the surface water layer. This suggests that the more probable reason for pycnocline development in the Silesian-Kraków area was thermal stratification of water column.

In modern seas, the thermocline usually develops during the summer and breaks down in winter, due to strong storm mixing. In the Polish Basin, suboxic conditions prevailed during the whole time of black shale deposition, but were interrupted by recurrent oxygenation periods of variable duration. The shortest are recorded by scattered trace fossils associated with thin silt-sand laminae and by bedding plane accumulations of the bivalve Bositra. In modern seas, benthic communities recolonize a deserted sea floor during the winter months (Tyson and Pearson 1991; Tagliapietra et al. 1998). The origin of monospecific bivalve event assemblages, covering bedding planes in ancient black shales, is commonly explained by oxygenation improvement linked with currents generated by single storms (e.g., Wignall and Myers 1988; Sageman 1989). Similarly, bioturbated horizons containing burrows of "doomed pioneers" are interpreted as a result of single gravity or hyperpycnal flows, responsible for an influx of an allochthonous fauna to inhospitable anoxic settings (Föllmi and Grimm 1990). Taking into account that the conditions in the Polish Basin were never truly anoxic and developed in an area of limited extent, the recolonization of the sea floor by opportunistic organisms could have occurred quite fast, even after a single strong storm.

Thicker bioturbated intervals, up to $10 \mathrm{~cm}$ thick, which occur in facies $M_{a}$, record longer-lasting periods of bottom oxygenation; however, their duration may be estimated only approximately. As was mentioned above, sedimentation of the ore-bearing clay was dominated by depositional events, including fall-out from fine-grained suspension currents and fluid mud layers moved by wave-induced turbidity currents (Leonowicz 2013, 2015a). The recent studies of sedimentary processes on the continental shelf in northern California show that the latter process can lead to deposition of a mud layer $6-13 \mathrm{~cm}$ thick during a single depositional event (Traykovski et al. 2000). This value increases to $44 \mathrm{~cm}$ at sites located off the delta front of the largest 


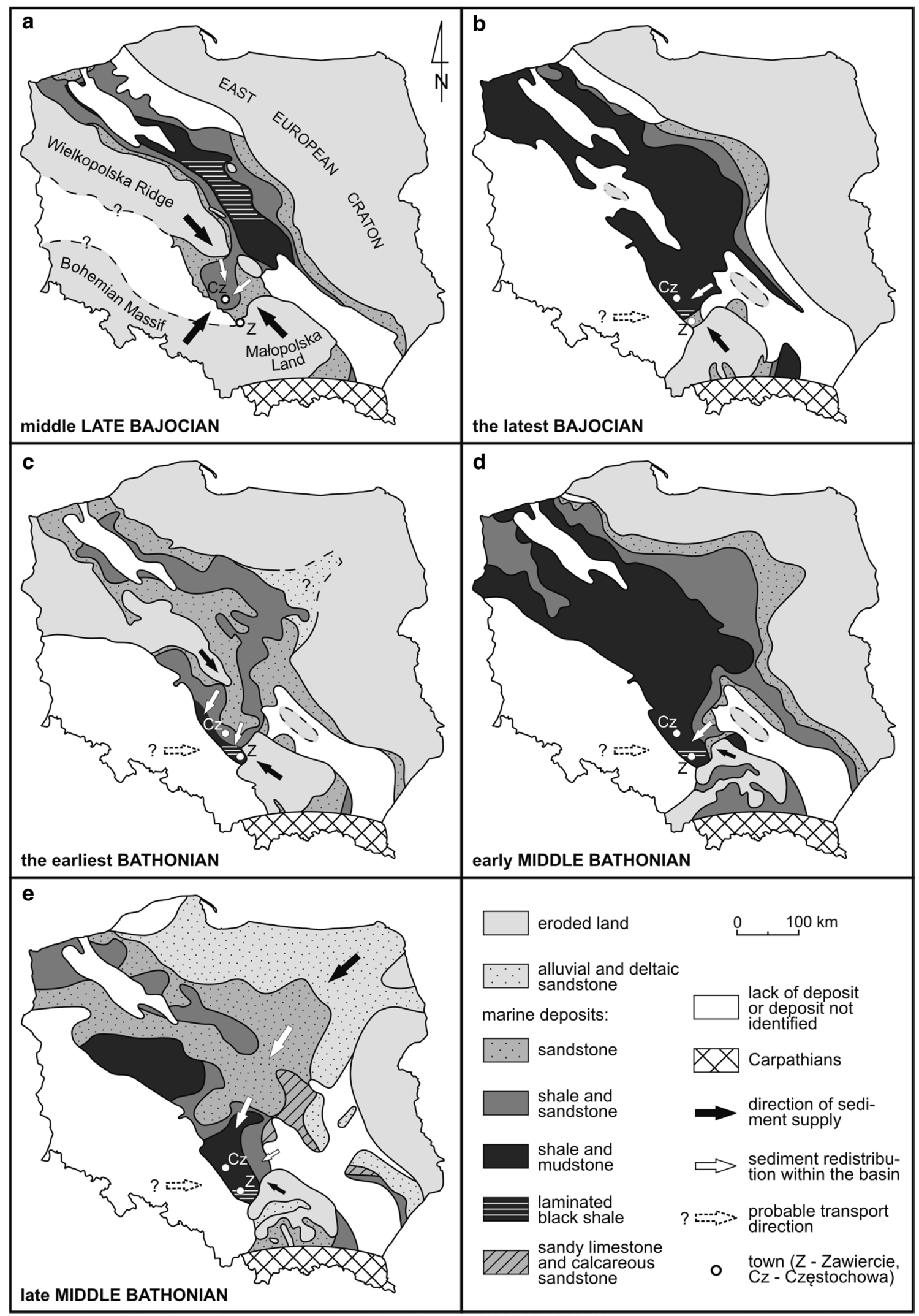

Fig. 9 Proposed directions of sediment supply to the SilesianKraków region during the Middle Jurassic. Paleogeographical maps of the Polish Basin after Feldman-Olszewska (1998) and Dayczak-
Calikowska (1997), modified; the southern part has been changed according to Barski (1999), Kozłowska et al. (2015) and own observations 
rivers, such as the Amazon (Sternberg et al. 1996). Assuming $85 \%$ porosity of the fresh mud (cf. Schieber and Yawar 2009), the thickness of such layers after total compaction ( $0 \%$ porosity) would decrease approximately to $1-2 \mathrm{~cm}$ and $6.5 \mathrm{~cm}$, respectively. Depositional processes in the epicontinental Polish Basin were likely less effective than on the continental shelf of California. However, even if it is assumed that a $1-\mathrm{cm}$-thick mudstone layer records deposition during one whole year, not only one depositional event, the accumulation of a $10-\mathrm{cm}$-thick bed would take 10 years. Accumulation of a $0.5-\mathrm{cm}$-thick layer, which is the thinnest bedding unit in facies $\mathrm{M}_{\mathrm{a}}$, would take half a year; thus, alternations of such thin bioturbated and laminated intervals could reflect seasonal changes of seafloor oxygenation.

\section{The source of sediment}

The succession of facies within the ore-bearing clay provides some information about the source of sediment. Generally, the first facies appearing above the shallow-marine sandstone is finely laminated claystone $\left(\mathrm{C}_{1}\right)$. Upwards, it passes into laminated deposits of facies $M_{1}$ and $M_{a}$, which in turn are overlain by bioturbated mudstone of facies $\mathrm{M}_{\mathrm{h}}$ and $\mathrm{M}_{\mathrm{m}}$. Taking into account that event silt-sand accumulations in facies $\mathrm{M}_{1}$ and $\mathrm{M}_{\mathrm{a}}$ are more common and thicker than in facies $\mathrm{C}_{1}$, the sequence is displaying an upward coarsening of grain size. A similar trend was observed in the bioturbated mudstone from Częstochowa, in which the highest total sand and silt content was noted in the upper part of succession (Leonowicz 2015a). The grain size generally depends on the energy of the transporting agent, length of the transport path, and the sediment type in the source area. If the first two agents are assumed, the upwardcoarsening trend could indicate a regression of the shoreline. However, earlier studies (e.g., Dayczak-Calikowska and Moryc 1988; Feldman-Olszewska 1998) have shown that the deposition of ore-bearing clay was associated with basin expansion, i.e., transgression of its shoreline. The other explanation of the upward-coarsening trend may be the changes taking place in source area.

An analysis of paleogeographical maps of the Polish Basin shows several potential sources of clastic material (Fig. 9). The nearest emergent area, which could have supplied sediment to the Silesian-Kraków region, was Małopolska Land. The transgressing sea firstly reworked alluvial sand of the Upper Toarcian Borucice Formation, which was probably partly incorporated into the Kościelisko Beds. However, Lower Jurassic deposits wedge out near Zawiercie and south of it Middle Jurassic rocks lie directly on claystone, mudstone, and carbonate of Triassic age (Dayczak-Calikowska 1997; Senkowiczowa 1998). It shows that in the early Middle Jurassic such fine-grained sediments cropped out at the surface and could have been eroded by a transgressing sea. As they contain only subordinate alternations of coarser-grained siliciclastics, they could not be an efficient source of sand and silt for event laminae present in the ore-bearing clay. Nonetheless, they could derive significant amounts of clay that could well explain the occurrence of clay-rich deposits at the base of the sequence. The increase of sand and silt content higher in the succession indicates that along with the progressive southward shift of the shoreline, the role of Małopolska Land would have diminished in favor of other sources.

The Bohemian Massif could serve as an important source of clastic material until the Late Bajocian transgression, which is recorded by significant expansion of the shale and mudstone lithofacies towards the southwest (Fig. 9a, b). It is not clear if this land was flooded completely or only in the marginal part; however, the contribution of clastics from the Bohemian Massif undoubtedly decreased. The Wielkopolska Ridge could be the source of coarser material until the Early Bathonian, except during the latest Bajocian peak transgression, when it was almost completely flooded (Fig. 9a-c). The other land, which could have supplied sediment to the Silesian-Kraków region, was an island located to the northeast of Małopolska Land, the existence of which is inferred from the lithofacies pattern (Fig. 9c, d) and transport directions measured in sandstone from this part of the basin (Kozłowska et al. 2015). The sediment could have been redistributed from there by long-shore currents until the Middle Bathonian. From the late Middle Bathonian, the most probable source of clastic material was a wide sandy shoreface, supplied with sediment from the East-European Craton (Fig. 9e). The progradation of this sand during the Middle Bathonian (Figs. 9d, e) could well explain the upward increase in sand content in the upper part of the ore-bearing clay (Leonowicz 2015a), which was accompanied by the increased rate of sedimentation, recorded by facies $\mathrm{M}_{\mathrm{m}}$. A similar coarsening-up trend may be traced in the Bathonian succession from central Poland (Feldman-Olszewska 2007, 2008, 2012), which suggests a common provenance of clastic material and reinforces the above interpretation. The same transport direction has been indicated by Marynowski et al. (2007) based on the composition of organic matter from the Middle Jurassic mudstones from different parts of the Polish Basin.

The proposed reconstruction of transport paths requires further verification by basin-wide investigations and more precise dating of core material. However, it shows that deposition of the ore-bearing clay was influenced by local as well as regional controlling factors. The rate of sediment accumulation depended mostly on its supply from the main source areas, i.e., its redistribution from the shoreface zones of lands bordering the Polish Basin. From this point of view, the Silesian-Kraków region was mostly in a distal 
location, which is reflected by the character of event laminae representing distal tempestites. The oxygenation of the sea floor resulted from local conditions, which developed in the vicinity of Małopolska Land and were influenced by the rate of terrigenous $\mathrm{OM}$ and nutrient delivery as well as the stability of the pycnocline. Such a complex origin and multi-factor control could well explain the lack of a clear correlation of the black shale intervals with the TR cycles distinguished in the ore-bearing clay. Sedimentation in the Polish Basin was strongly influenced by syndepositional faults and salt movements, which led to differentiation of the sea floor with several elevations and depocenters (Dadlez 1994; Feldman-Olszewska 1997; Barski 1999; Pienkowski et al. 2008). The internal configuration of the basin changed with time, which explains the postulated changes of source area. The TR cycles from the ore-bearing clay succession were interpreted based on the variation of sand, silt, and clay contents and, in addition to relative sea-level changes in the Polish Basin, they also record several events of local extent (Leonowicz 2015a). For example, regression $R_{2}$ was probably caused by syndepositional uplift of the southern part of the Wielkopolska Ridge, whereas regression $\mathrm{R}_{6}$ likely resulted from the local autocyclic progradation of the shoreline (Leonowicz 2015a). Formation of black shale, in turn, was closely linked with transgression of the sea across Małopolska Land, which was probably caused by spreading and deepening of the Tethyan Ocean to the south (Matyja 2015) and had only limited influence on the grain-size composition of mudstone.

\section{Conclusions}

The transgression of the Middle Jurassic sea, which covered the Silesian-Kraków region during Bajocian and Bathonian time, led to the development of oxygen-deficient conditions in the vicinity of Małopolska Land, resulting in the deposition of black shale. The black shale constitutes part of the ore-bearing clay succession and is represented by three facies: laminated mudstone $\left(\mathrm{M}_{1}\right)$, laminated claystone $\left(\mathrm{C}_{1}\right)$ and alternating laminated and bioturbated mudstone $\left(\mathrm{M}_{\mathrm{a}}\right)$. Two other facies types distinguished in the ore-bearing clay, homogenized mudstone $\left(\mathrm{M}_{\mathrm{h}}\right)$ and mottled mudstone $\left(\mathrm{M}_{\mathrm{m}}\right)$, record less restrictive dysoxic conditions. Detailed analysis of sedimentary structures indicates that black shale was deposited in a relatively shallow (several tens of meters deep) environment, characterized by frequent reworking of the bottom by storm-generated currents.

The impoverished trace fossil and benthic faunal associations indicate that the black shale formed in suboxic conditions, prevailing within the sediment and on the sea floor, and these were repeatedly interrupted by episodes of oxygenation. The development of oxygen deficiency resulted most probably from the increased supply of organic matter, from both the land and phytoplankton blooms, and its decay below the pycnocline that led to rapid oxygen consumption. Re-oxygenation events were likely linked with water column mixing during storms and varied in duration. The shortest, recorded by event laminae from $M_{1}$ and $C_{1}$ facies, were probably linked with single storms. Bioturbated layers $0.5 \mathrm{~cm}$ thick from $\mathrm{M}_{\mathrm{a}}$ facies could reflect seasonal changes of the seafloor oxygenation. The thickest bioturbated units record intervals lasting several tens of years.

The studied black shale is associated with the lower part of a transgressive systems tract and represents a nearshore transgressive (TN) black shale. It formed in a narrow proximal zone, in the vicinity of Małopolska Land. Onshore, it merges with a condensed shallower-water deposit, whereas offshore it passes into better-oxygenated bioturbated mudstone. In contrast to the model of Wignall and Newton (2001), in the most proximal settings laminated facies formed during both transgressions and regressions, whereas in distal locations whole transgressive-regressive cycles are recorded by bioturbated mudstone. The limited extent of the black shale belt indicates that it does not belong to the thick black shale complex deposited in the central part of the Polish Basin during times of considerable increase in water depth (cf. Feldman-Olszewska 2005).

Deposition of the studied deposits was influenced by regional and local effects. The rate of accumulation depended on the sediment supply from lands bordering the Polish Basin, including Małopolska Land, the Bohemian Massif, Wielkopolska Ridge, East-European Craton, and an island situated to the northeast of Małopolska Land. Their share in sediment delivery changed with time along with progress of the transgression and as a result of syndepositional tectonics. Oxygen deficiency, in turn, resulted from the local conditions, which developed in the vicinity of Małopolska Land and played a key role in black shale deposition. The present study shows that formation of nearshore transgressive black shale in a sedimentary basin, which was characterized by unequal subsidence of the sea floor linked with syndepositional tectonics, depended mainly on local factors and might not reflect sea-level changes of global and regional extent.

Acknowledgments The authoress would like to thank A. SchmidRöhl and an anonymous reviewer whose corrections and comments substantially helped me to revise the manuscript. I also thank M. Tucker, the journal editor, for useful remarks and kind help with editorial matters and language corrections. The managements of brickyards: "Alina", "Sowa”, CEGBUD Gliński, Leszczyński-Wytrzymały, "Anna" and Wienerberger Gnaszyn in Częstochowa as well as "Keram" in Ogrodzieniec and brickyards in Blanowice and Żarki are thanked for providing access to their workings. The research was financed by Institute of Geology, University of Warsaw. 
Open Access This article is distributed under the terms of the Creative Commons Attribution 4.0 International License (http://creativecommons.org/licenses/by/4.0/), which permits unrestricted use, distribution, and reproduction in any medium, provided you give appropriate credit to the original author(s) and the source, provide a link to the Creative Commons license, and indicate if changes were made.

\section{References}

Arthur MA, Sageman BB (1994) Marine black shales: depositional mechanisms and environments of ancient deposits. Annu Rev Earth Planet Sci 22:499-551

Barski M (1999) Dinocyst stratigraphy of the Jurassic black clays from Holy Cross Mts area (Central Poland) (in Polish with English summary). Przeg Geol 47:718-722

Barski M, Dembicz K, Praszkier T (2004) Biostratigraphy and the Mid-Jurassic environment from the Ogrodzieniec quarry (in Polish with English summary). Tomy Juraj 2:61-68

Dadlez R (1989) Epicontinental Permian and Mesozoic basins in Poland (in Polish with English summary). Kwart Geol 33:175-198

Dadlez R (1994) Strike-slip movements in the Polish Lowlands. Geol Q 38:307-318

Dadlez R, Kopik J (1975) Stratigraphy and palaeogeography of the Jurassic. Biul Inst Geol 252:149-171

Dadlez R, Marek S, Pokorski J (eds) (2000) Geological map of Poland without Cainozoic deposits, 1:1 000 000. Państwowy Instytut Geologiczny, Warszawa

Dayczak-Calikowska K (1997) Middle Jurassic: Sedimentation, palaeogeography and palaeotectonics (in Polish). In: Marek S, Pajchlowa M (eds) Epicontinental Permian and Mesozoik in Poland. Pr Państw Inst Geol, vol 153, pp 269-282

Dayczak-Calikowska K, Moryc W (1988) Evolution of sedimentary basin and palaeotectonics of the Middle Jurassic in Poland (in Polish with English summary). Kwart Geol 32:117-136

Dayczak-Calikowska K, Feldman-Olszewska A, Kasiński J, Marek S, Niemczycka T (2008) Szczegółowy profil litologiczno-stratygraficzny otworu wiertniczego Brześć Kujawski IG 2 (in Polish). In: Feldman-Olszewska A (ed) Profile Głębokich Otworów Wiertniczych Państwowego Instytutu Geologicznego, vol 125, pp 65-88

Demaison GJ, Moore GT (1980) Anoxic environments and oil source bed genesis. Am Assoc Petrol Geol Bull 64:1179-1209

Droser ML, Bottjer DJ (1986) A semiquantitative field classification of ichnofabric. J Sediment Res 56:558-559

Feldman-Olszewska A (1997) Depositional architecture of the Polish epicontinental Middle Jurassic basin. Geol Q 41:491-508

Feldman-Olszewska A (1998) Palaeogeographical maps of Middle Jurassic. In: Dadlez R, Marek S, Pokorski J (eds) Palaeogeographical atlas of the epicontinental Permian and Mesozoic in Poland. Państwowy Instytut Geologiczny, Warszawa, pp 36-47

Feldman-Olszewska A (2005) Środowiska sedymentacji w jurze środkowej Kujaw (in Polish). PhD thesis, Państwowy Instytut Geologiczny

Feldman-Olszewska A (2007) Jura środkowa. Analiza sedymentologiczna (in Polish). In: Feldman-Olszewska A (ed) Profile Głębokich Otworów Wiertniczych Państwowego Instytutu Geologicznego, vol 117, pp 54-65

Feldman-Olszewska A (2008) Jura. Wyniki badań sedymentologicznych utworów jury środkowej w otworach wiertniczych Brześć Kujawski IG 2 i Brześć Kujawski IG 3 (in Polish). In: FeldmanOlszewska A (ed) Profile Głębokich Otworów Wiertniczych Państwowego Instytutu Geologicznego, vol 125, pp 151-157

Feldman-Olszewska A (2012) Jura. Wyniki badań sedymentologicznych utworów jury środkowej w otworach wiertniczych
Wojszyce IG 1a, Wojszyce IG 3 i Wojszyce IG 4 (in Polish). In: Feldman-Olszewska A (ed) Profile Głębokich Otworów Wiertniczych Państwowego Instytutu Geologicznego, vol 137, pp 149-166

Föllmi KB, Grimm KA (1990) Doomed pioneers: gravity-flow deposition and bioturbation in marine oxygen-deficient environments. Geology 18:1069-1072

Gedl P, Kaim A, Leonowicz P, Boczarowski A, Dudek T, Kędzierski M, Rees J, Smoleń J, Szczepanik P, Sztajner P, Witkowska M, Ziaja J (2012) Palaeoenvironmental reconstruction of Bathonian (Middle Jurassic) ore-bearing clays at Gnaszyn, Kraków-Silesia Homocline, Poland. Acta Geol Polon 62:463-484

Hallam A, Bradshaw MJ (1979) Bituminous shales and oolitic ironstones as indicators of transgressions and regressions. J Geol Sci 136:157-164

Immenhauser A (2009) Estimating palaeo-water depth from the physical rock record. Earth-Sci Rev 96:107-139

Jenkyns HC (1985) The Early Toarcian and Cenomanian-Turonian anoxic events in Europe: comparisons and contrasts. Geol Rundsch 74:505-518

Jenkyns HC (1988) The Early Toarcian (Jurassic) anoxic event: stratigraphic, sedimentary, and geochemical evidence. Am J Sci 288:101-151

Jenkyns HC, Gröcke DR, Hesselbo SP (2001) Nitrogen isotope evidence for water mass denitrification during the early Toarcian (Jurassic) oceanic anoxic event. Paleoceanography 16:593-603

Katz BJ (2005) Controlling factors on source rock development-a review of productivity, preservation, and sedimentation rate. In: Harris NB (ed) The deposition of organic-carbon-rich sediments: models, mechanisms, and consequences. SEPM Spec Publ, vol 82 , pp 7-16

Klemme HD, Ulmishek GF (1991) Effective petroleum source rocks of the world: stratigraphic distribution and controlling depositional factors. AAPG Bull 75:1809-1851

Kopik J (1997) Middle Jurassic: formal and informal stratigraphic units-Polish Jura (in Polish). In: Marek S, Pajchlowa M (eds) Epicontinental Permian and Mesozoik in Poland. Pr Państw Inst Geol, vol 15, pp 263-264

Kopik J (1998) Lower and Middle Jurassic of the north-eastern margin of the Upper Silesian Coal Basin (in Polish with English summary). Biul Państw Inst Geol 378:67-129

Kozłowska M, Barski M, Mieszkowski R, Antoszewska K (2015) A new Triassic-Jurassic section in the southern part of the Holy Cross Mts (Poland) - implications for palaeogeography. Geol Q 60. doi:10.7306/gq.1259

Kutek J (1994) Jurassic tectonic events in south-eastern cratonic Poland. Acta Geol Polon 44:167-221

Leonowicz P (2013) The significance of mudstone fabric combined with palaeoecological evidence in determining sedimentary processes-an example from the Middle Jurassic of southern Poland. Geol Q 7:243-260

Leonowicz P (2015a) Storm-influenced deposition and cyclicity in a shallow-marine mudstone succession-example from the Middle Jurassic ore-bearing clays of the Polish Jura (southern Poland). Geol Q 59:325-344

Leonowicz P (2015b) Ichnofabrics of shallow-marine mudstone, the result of changing environmental conditions: an example from the Middle Jurassic ore-bearing clay from southern Poland. Facies. doi:10.1007/s10347-015-0438-4

Marcinkiewicz T (1980) Jurassic megaspores from Grojec near Kraków. Acta Palaeobot 21:37-60

Marynowski L, Zatoń M, Simoneit BRT, Otto A, Jędrysek MO, Grelowski C, Kurkiewicz S (2007) Compositions, sources and depositional environments of organic matter from the Middle Jurassic clays of Poland. Appl Geochem 22:2456-2485 
Matyja BA (2015) Jurajska ewolucja północnego obrzeża Tetys (in Polish). Przewodnik LXXXIV Zjazdu Naukowego PTG, 9-11.09.2015, pp 28-40

Matyja BA, Wierzbowski A (2000) Ammonites and stratigraphy of the uppermost Bajocian and Lower Bathonian between Częstochowa and Wieluń, Central Poland. Acta Geol Polon 50:191-209

Matyja BA, Wierzbowski A (2003) Ammonite biostratigraphy of the Ore-Bearing Częstochowa Clay Formation (uppermost Bajocian-Upper Bathonian) from exposures in Częstochowa (in Polish). Tomy Juraj 1:3-6

Matyja BA, Wierzbowski A (2006a) European platform. introduction. Middle and Upper Jurassic. In: Wierzbowski A et al (eds) Jurassic of Poland and adjacent Slovakian Carpathians. Field trip guidebook. 7th International Congress on the Jurassic System, 6-18 September 2006, Kraków, pp 130-131

Matyja BA, Wierzbowski A (2006b) Field Trip B1-Biostratigraphical framework from Bajocian to Oxfordian. Stop B1.5-Sowa's and Gliński's clay pits (uppermost Bajocian-lowermost Bathonian). Ammonite biostratigraphy. In: Wierzbowski A et al (eds) Jurassic of Poland and adjacent Slovakian Carpathians. Field trip guidebook. 7th International Congress on the Jurassic System, 6-18 September 2006, Kraków, pp 149-151

McArthur JM, Algeo TJ, van de Schootbrugge B, Li Q, Howarth RJ (2008) Basinal restriction, black shales, Re-Os dating, and the Early Toarcian (Jurassic) oceanic anoxic event. Paleoceanography 23:PA4217

Pieńkowski G, Schudack ME, Bosák P, Enay R, Feldman-Olszewska A, Golonka J, Gutowski J, Herngreen GFW, Jordan P, Krobicki M, Lathuiliere B, Leinfelder RR, Michalík J, Mönnig E, NoeNygaard N, Pálfy J, Pint A, Rasser MW, Reisdorf AG, Schmid DU, Schweigert G, Surlyk F, Wetzel A, Wong TE (2008) Jurassic. In: McCann T (ed) The geology of Central Europe. Volume 2: Mesozoic and Cenozoic. Geological Society of London, pp 823-922

Röhl H-J, Schmid-Röhl A (2005) Lower Toarcian (Upper Liassic) black shales of the Central European epicontinental basin: a sequence stratigraphic case study from the SW German Posidonia Shale. In: Harris NB (ed) The deposition of organic-carbonrich sediments: models, mechanisms, and consequences. SEPM Spec Publ 82, pp 165-189

Różycki SZ (1953) Górny dogger i dolny malm Jury KrakowskoCzęstochowskiej (in Polish). Pr Inst Geol 17:1-412

Sageman BB (1989) The benthic boundary biofacies model: Hartland Shale Member, Greenhorn Formation (Cenomanian), Western Interior, North America. Palaeogeogr Palaeoclimatol Palaeoecol 74:87-110

Sageman BB, Wignall PB, Kauffman EG (1991) Biofacies models for oxygen-deficient facies in epicontinental seas: tool for paleoenvironmental analysis. In: Einsele G, Ricken W, Seilacher A (eds) Cycles and events in stratigraphy. Springer-Verlag, Berlin, Heidelberg, pp 542-564

Schieber J, Yawar Z (2009) A new twist on mud deposition-mud ripples in experiment and rock record. Sediment Rec 7:4-8

Senkowiczowa H (1998) Triassic of the north-eastern margin of the Upper Silesian Coal Basin (in Polish with English summary). Biul Państw Inst Geol 378:5-66

Słowakiewicz M, Tucker ME, Perri E, Pancost RD (2015) Nearshore euxinia in the photic zone of an ancient sea. Palaeogeogr Palaeoclimatol Palaeoecol 426:242-259

Sternberg RW, Cacchione DA, Paulson TB, Kineke GC, Drake DE (1996) Observations of sediment transport on the Amazon subaqueous delta. Cont Shelf Res 16:697-715
Świdrowska J (1994) Direction of the Aalenian transgression in the area of the Mid-Polish Trough. Geol Q 38:319-336

Szczepanik P (2006) Pirytyzacja szczątków biogenicznych w ciemnych utworach Wyżyny Krakowsko-Częstochowskiej (in Polish). $\mathrm{PhD}$ thesis, Jagiellonian University

Szczepanik P, Witkowska M, Sawłowicz Z (2007) Geochemistry of Middle Jurassic mudstones (Kraków-Częstochowa area, southern Poland): interpretation of the depositional redox conditions. Geol Q 51:57-66

Tagliapietra D, Pavan M, Wagner C (1998) Macrobenthic community changes related to eutrophication in Palude della Rosa (Venetian Lagoon, Italy). Estuar Coast Shelf Sci 47:217-226

Traykovski P, Geyer WR, Irish JD, Lynch JF (2000) The role of waveinduced density-driven fluid mud flows for cross-shelf transport on the Eel River continental shelf. Cont Shelf Res 20:2113-2140

Tyson RV (1987) The genesis and palynofacies characteristics of marine petroleum source rocks. Geol Soc Spec Publ 26:47-67

Tyson RV (2005) The "productivity versus preservation" controversy: cause, flaws, and resolution. In: Harris NB (ed) The deposition of organic-carbon-rich sediments: models, mechanisms, and consequences. SEPM Spec Publ, vol 82, pp 17-33

Tyson RV, Pearson TH (1991) Modern and ancient continental shelf anoxia: an overview. Geol Soc Spec Publ 58:1-24

Wetzel A (1991a) Stratification in black shales: depositional models and timing — an overview. In: Einsele G, Ricken W, Seilacher A (eds) Cycles and events in stratigraphy. Springer-Verlag, Berlin, Heidelberg, pp 508-527

Wetzel A (1991b) Ecologic interpretation of deep-sea trace fossil communities. Palaeogeogr Palaeoclimatol Palaeoecol 85:47-69

Wetzel A (2008) Recent bioturbation in the deep South China Sea: a uniformitarian ichnologic approach. Palaios 23:601-615

Wetzel A, Uchman A (1998) Biogenic sedimentary structures in mudstones-an overview. In: Schieber J, Zimmerle W, Sethi PS (eds) Shales and mudstones. I. E. Schweizerbart'sche Verlagsbuchhlandlung, Stuttgart, pp 351-369

Wignall PB (1991) Model for transgressive black shales? Geology 19:167-170

Wignall PB (1994) Black shales. Oxford University Press, Oxford

Wignall PB, Hallam A (1991) Biofacies, stratigraphic distribution and depositional models of British onshore Jurassic black shales. Geol Soc Spec Publ 58:291-309

Wignall PB, Myers KJ (1988) Interpreting benthic oxygen levels in mudrocks: a new approach. Geology 16:452-455

Wignall PB, Newton R (2001) Black shales on the basin margin: a model based on examples from the Upper Jurassic of the Boulonnais, northern France. Sediment Geol 144:335-356

Zatoń M (2007) Amonity z iłów rudonośnych (bajos-baton) Jury Polskiej (in Polish). PhD thesis, University of Silesia

Zatoń M, Marynowski L, Szczepanik P, Bond DPG, Wignall PB (2009) Redox conditions during sedimentation of the Middle Jurassic (Upper Bajocian-Bathonian) clays of the Polish Jura (south-central Poland). Facies 55:103-114

Zatoń M, Machocka S, Wilson MA, Marynowski L, Taylor PD (2011) Origin and paleoecology of Middle Jurassic hiatus concretions from Poland. Facies 57:275-300

Zatoń M, Kremer B, Marynowski L, Wilson MA, Krawczyński W (2012) Middle Jurassic (Bathonian) encrusted oncoids from the Polish Jura, southern Poland. Facies 58:57-77

Ziegler PA (1990) Geological atlas of western and central Europe. Shell Internationale Petroleum Maatschappij BV, The Hague 